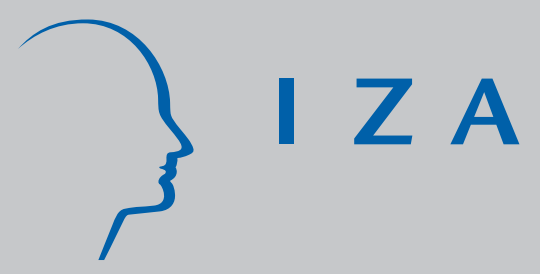

IZA DP No. 3207

The NAFTA Tide: Lifting the Larger and Better Boats

Angel Calderon-Madrid

Alexandru Voicu

December 2007 


\title{
The NAFTA Tide: Lifting the Larger and Better Boats
}

\author{
Angel Calderon-Madrid \\ El Colegio de México \\ Alexandru Voicu \\ CUNY, College of Staten Island \\ and IZA
}

\section{Discussion Paper No. 3207 \\ December 2007}

\author{
IZA \\ P.O. Box 7240 \\ 53072 Bonn \\ Germany \\ Phone: +49-228-3894-0 \\ Fax: +49-228-3894-180 \\ E-mail: iza@iza.org
}

\begin{abstract}
Any opinions expressed here are those of the author(s) and not those of the institute. Research disseminated by IZA may include views on policy, but the institute itself takes no institutional policy positions.

The Institute for the Study of Labor (IZA) in Bonn is a local and virtual international research center and a place of communication between science, politics and business. IZA is an independent nonprofit company supported by Deutsche Post World Net. The center is associated with the University of Bonn and offers a stimulating research environment through its research networks, research support, and visitors and doctoral programs. IZA engages in (i) original and internationally competitive research in all fields of labor economics, (ii) development of policy concepts, and (iii) dissemination of research
\end{abstract} results and concepts to the interested public.

IZA Discussion Papers often represent preliminary work and are circulated to encourage discussion. Citation of such a paper should account for its provisional character. A revised version may be available directly from the author. 


\section{ABSTRACT}

\section{The NAFTA Tide: Lifting the Larger and Better Boats ${ }^{\star}$}

We use panel data on Mexican manufacturing plants to study the connection between plants' responses to changes in the economic environment and their contributions to aggregate productivity growth in the period following the implementation of the North American Trade Agreement (NAFTA). In all industries, an overwhelming share of aggregate productivity growth is accounted for by a small number of plants which were larger and more productive before the implementation of NAFTA and expanded and became more productive following the implementation of NAFTA. Plants that exported before NAFTA and export continuously through 2000 and some of the new exporters are more likely to be among the top-performing plants. Exporting activity and performance of plants with similar exporting experience, however, display remarkable heterogeneity. This heterogeneity implies that trade liberalization provided growth opportunity to larger and more productive plants irrespective of their export status and provides an explanation for the lackluster average productivity performance of exporting plants.

JEL Classification: C13, D24, F13, O47, O54

Keywords: NAFTA, trade liberalization, productivity, heterogeneity of plant-level performance

Corresponding author:

Alexandru Voicu

CUNY, College of Staten Island

PEP Department

2800 Victory Blvd.

Staten Island, NY 10314

USA

E-mail: voicu@mail.csi.cuny.edu

\footnotetext{
* The authors are grateful to John Haltiwanger, Adriana Kugler, Eric Verhoogen, the participants of the conference "Job Reallocation, Productivity Dynamics and Trade Liberalization," (Bogota, 2005), the participants of the Bank of Mexico Direccion General de Investigacion Economica seminar (July 2005), and Michael Lahr for their many comments and suggestions. The help from Abigael Duran of the Mexican National Institute of Statistics, INEGI, in Aguascalientes, Mexico, were very useful in the elaboration of this paper. We are grateful to him, to Alex Cano, and to the staff of INEGI for making this research possible. The conclusions expressed here and remaining errors are exclusive responsibility of the authors.
} 


\section{Introduction}

The relationship between plants' exporting activity and their productivity performance has been the focus of recent empirical and theoretical trade literature. ${ }^{3}$ The existence of plant-level productivity gains from exporting is important from a policy perspective. ${ }^{4}$ Post-entry productivity gains involvement in the export markets may raise returns to innovation, alow plants to exploit economies of scale, or force them to reduce X-inefficiency - as well as pre-entry productivity gains, if plants have to become more productive in order to enter the export markets, justify trade promotion and trade liberalization policies. Without productivity gains from exporting, trade promotion policies lead to plants self-selecting into subsidies and, potentially, incurring the considerable downside risks of exporting.

Previous studies of trade liberalization episodes and periods with rapidly falling trade $\operatorname{costs}^{5}$ reveal that reductions in the costs of trade lead to higher aggregate, industry-level productivity - the efficiency with which industry's output is produced - but little if any of this growth comes from plant-level efficiency gains related to exporting activity. Evidence with respect to the relationship between exporting and post-entry productivity growth is weak: future performance of current exporters is at best as good as that of plants that do not export. Instead, the link between the reduction in the costs of trade and aggregate productivity growth lies in the correlation between plants' characteristics and plants' responses to trade liberalization. ${ }^{6}$ In industries with heteroge-

\footnotetext{
${ }^{3}$ Tybout (2003) and Greenway and Kneller (2007) provide reviews of the literature on the relationship between plant performance, exporting, and foreign investment.

${ }^{4}$ Bernard and Jensen (1999)

${ }^{5}$ Pavcnik (2002), Tybout and Westbrook (1995) and Lopez-Cordova (2002) study trade liberalization episodes in Chile and Mexico; Bernard, Jensen, and Schott (2006) use data on US manufacturing plants that cover the period between 1982 and 1997 during which tariffs declined by more than 25 percent in a majority of industries.

${ }^{6}$ Melitz (2004), Helpman, Melitz, and Yeaple (2004), Bernard, Eaton, Jensen, and Kortum (2003) propose theoretical models of imperfectly competitive industries with heterogeneous firms in which the link between the reduction in the costs of trade and aggregate productivity growth lies in the correlation between plants' productivity and plants' responses to trade liberalization.
} 
neous plants and fixed costs of exporting, more productive plants become exporters. Reductions in trade costs force least-productive firms to exit the market, increase the number of exporters more productive firms become exporters - enhance sales by existing exporters, and reduce domestic market share of surviving firms. This trade-induced reallocation of market share from less to more productive plants leads to aggregate, industry-level productivity growth in the absence of plant-level productivity gains from exporting.

Plants that undertake exporting activities, however, meet with various degrees of success. ${ }^{7}$ There is significant, simultaneous entry into and exit from the export market and changes in export status represent important junctures in plants' lives. For a short period following entry into the foreign markets, exporting plants grow, on average, faster than plants that do not export. Over time, some of them will fail and exit the export market. The performance of plants that exit is, on average, weaker than that of plants that never export, while those that continue their export operations grow faster than plants that never export. Over longer periods of time, due to this heterogeneity of exporting activity, the performance of plants that enter the export market at any given point in time is not, on average, better than that of plants that never export. These results suggest that, following trade liberalization, plants' contributions to aggregate productivity growth are far more heterogeneous than predicted by the theoretical models. They also leave open the possibility that, while, on average, exporting plants do not have better productivity performance than non-exporting plants, for a subset of plants a reduction in the costs of trade may lead to both output and productivity growth.

In this paper we use data on Mexican manufacturing plants to study the connection between plants' responses to changes in the economic environment and their contributions to aggregate pro-

\footnotetext{
${ }^{7}$ Bernard and Jensen $(1999,2004)$
} 
ductivity growth in the period following the implementation of the North American Trade Agreement (NAFTA). Our data, an unbalanced panel of non-maquiladora plants ${ }^{8}$ from eight two-digit industries, cover the period between 1993 and 2000, a period that, in addition to the introduction of NAFTA in 1994, encompassed a severe macroeconomic crisis in 1995 and the temporary devaluation of the Mexican peso. We document the intra-industry heterogeneity of plants' responses to the changes in the economic environment paying special attention to changes in the export status. We estimate plant-level total factor productivity and use principal component analysis to study the intra-industry variation in the joint productivity and output performance, the determinants of the magnitude and nature of plants' contributions to aggregate productivity. Finally, using the results of the principal component analysis we analyze the contributions to aggregate productivity growth of plants with different types of responses to the changes in the economic environment as well as the heterogeneity of the contributions of firms with similar responses.

We find strong, export-driven, aggregate output and productivity growth in the Mexican manufacturing sector between 1993 and 2000. Exporting and plant-level performance are connected. In all industries, an overwhelming share of aggregate productivity growth is accounted for by a small number of plants (roughly 70 percent of percent of the aggregate productivity growth is concentrated in 10 percent of the plants). These plants were much larger and more productive than average before the implementation of NAFTA, and they expanded and became more productive following the implementation of NAFTA. Plants that exported before NAFTA and export continuously through 2000 and some new entrants have significantly higher probability of being in the top-performing group. Exporting activity and performance of plants with similar exporting experience, however, display remarkable heterogeneity. This heterogeneity implies, on the one hand, that

\footnotetext{
${ }^{8} \mathrm{~A}$ maquiladora or maquila is a factory that imports materials and equipment on a duty-free and tariff-free basis for assembly or manufacturing and then re-exports the assembled product, usually back to the originating country.
} 
trade liberalization provided growth opportunity to larger and more productive plants regardless of their export status. On the other hand, it generates aggregate patterns that differ from the predictions of the theoretical models. While plants that exported in 1993, especially those that continued to export until 2000, were larger to begin with and grew more than those that did not export, we find no evidence that exporting plants, even long-term exporters were, on average, more productive than non-exporters and, therefore, their expansion could not lead to aggregate productivity growth.

The remainder of the paper is structured as follows. Section 2 contains background information on NAFTA and a description of the data set used in this paper. In section 3 we analyze aggregate industry-level performance between 1993 and 2000 and document the heterogeneity of plants' responses to the changes in the economic environment. The estimation of industry-level production functions is presented in section 4 , together with an analysis of aggregate industry-level productivity. In section 5 we study the connection between plant-level responses to changes in the economic environment and plant-level contributions to aggregate productivity growth. We conclude with a summary of the main findings and a discussion of their implications.

\section{Background and Data}

In mid 1980s, as part of its accession to GATT, Mexico substantially reduced and rationalized tariffs and undertaken privatization, deregulation, and other major economic reforms. The North American Free Trade Agreement (NAFTA), signed in December 1992 and implemented in January 1994, was aimed at creating an integrated market in North America. NAFTA included provisions for progressive elimination of tariff and non-tariff barriers to goods trade, improvement of access for services trade, creation of a stable and transparent legal framework for foreign investors, stronger protection of intellectual property rights, and creation of an effective dispute settlement mechanism; 
NAFTA removed or phased out measures designed to discourage the free flow of capital between Canada, Mexico, and the US. Previous literature shows that NAFTA had an important effect on Mexico's economy: the volume of trade grew substantially, the composition of trade changed, FDI flows increased considerably, and total factor productivity grew faster in the manufacturing sector. ${ }^{9}$ In this paper we use an unbalanced panel data set of non-maquiladora manufacturing plants from eight two-digit industries: food processing, textiles, wood, paper, chemicals, glass, basic metals, and machinery. The plants were followed for eight years, between 1993 and 2000, which allows us to observe them both before and after the implementation of NAFTA. The data set was constructed using information from two main sources, Annual Industrial Survey (AIS) and Industrial Census (IC). AIS is a survey of manufacturing establishments that uses a non-probabilistic sample (the sample selection startegy is descibed in Appendix A.1). The sample was selected using IC 1993 as universe and included predominantly large and medium-scale plants, but also a significant number of small plants from 205 six-digit industries. Selected plants account for at least 80 percent of the total value of production of their respective industry. Establishments that operate under the special maquiladora regime and petrochemical and oil-refining plants, which are state-owned monopoly, are excluded from the sample. AIS provides information on a wide range of variables: investment and sales of capital, rent on buildings paid by the plant, value added, skilled and unskilled labor, electricity usage, total sales, domestic sales, and exports, and use of imported intermediary inputs. IC takes place every five years and in this paper we use information from the 1993 and 1998 surveys. IC contains information on replacement value and depreciation for six categories of capital stock: machinery, buildings, land, transportation equipment, computing and peripheral equipment, and

\footnotetext{
${ }^{9}$ Lederman, Maloney, and Serven (2003) use sectoral data and find faster convergence rates during NAFTA. Using firm-level evidence, Lopez-Cordova (2002) finds an increase in TFP in NAFTA years due to preferential access to the US market and import competition, but not from the use of imported inputs. Schiff and Wang (2003) use sector data and find that on the contrary use of imported intermediary inputs is responsible for TFP growth.
} 
furniture and office equipment. Firms are asked to consider reevaluations due to exchange rate variations and to account for physical deterioration and obsolescence.

We use information from the two sources to construct plant-level time series for a set of plant characteristics and measures of performance. We combine data on replacement value of the capital stock from the IC with data from AIS on investment and sales of capital, and rent on buildings paid by the plant to impute the replacement value of capital stock for each firm for all the years (a detailed description of the imputation procedure is given in the Appendix A.2). The imputed capital stock, value added, skilled and unskilled labor, and electricity usage are used to estimate the industry-specific production functions and construct plant-level total factor productivity series. Total, domestic, and export sales, shares of imported inputs, capital intensity, share of skilled labor, and foreign direct investment are used in the subsequent analysis. Value added and sales were deflated using a price index generated by INEGI for 205 sectors. We exclude from the analysis plants with missing information on the variables of interest for any of years they were present in the sample. Among plants that exit the AIS sample between 1993 and 2000, we use in the analysis only those that closed down (shut down, bankrupt, and liquidated). The resulting sample contains 4,127 plants and 30,534 plant-year observations, in eight manufacturing industries.

Like all other studies measuring the effect of NAFTA on the performance of Mexican plants, ours has two limitations. Our data set covers a period that, in addition to the implementation of NAFTA, encompasses a period of exchange rate devaluation, following the collapse of peso in December 1994, and a severe macroeconomic crisis. Effects of the unilateral policy of trade liberalization undertaken after 1985 were likely to be present after 1994 and, in turn, some NAFTA provisions will not be fully implemented until 2009. NAFTA itself was a nexus of provisions removal of tariff and non-tariff barriers to the goods trade, removal of barriers to service trade, 
creation of a stable and transparent legal framework for foreign investors, stronger protection of intellectual property rights. As a result, it is difficult to trace the effects of individual components of NAFTA, of NAFTA itself, or of the exchange rate devaluation on the performance of manufacturing plants. In this paper, we analyze plants' responses to the changes in the economic environment, specifically exits from the market and changes in the export status, and the relationship between these responses and plant-level performance. Second, initial conditions were asymmetric. Even after the unilateral trade liberalization, Mexico retained higher tariff and non-tariff barriers than both US and Canada. Therefore, it is expected that transition costs will be relatively higher for Mexico. By studying performance during a relatively short period after implementation, results are likely to be affected by the short-run transition costs.

\section{$3 \quad$ Aggregate industry-level performance}

We begin our empirical analysis with an assessment of the aggregate, industry-level performance of the Mexican manufacturing sector following the introduction of NAFTA. Table 1 presents the number of exporting plants, domestic sales, and export sales, in our sample, between 1993 and 2000. The data show tremendous overall growth in the Mexican manufacturing sector between 1993 and 2000, and suggest that stronger exporting activity following the introduction of NAFTA accounts for a large share of the aggregate growth. Overall, total sales increased by 56 percent and

roughly half of this growth is accounted for by the rise in exports: the number of exporting plants increased by 45 percent, export sales nearly doubled, while domestic sales increased by 32 percent. Aggregate performance varies widely over time and across industries. The highest rates of growth in exports prevail between 1995 and 1997, when the effects of NAFTA and those of the exchange rate devaluation overlap. On the other hand, the domestic crisis of 1995 had a strong negative effect 
on domestic sales in all industries. The machinery industry accounts for two thirds of the total exports made between 1993 and 2000 and for more than 75 percent of the growth in exports, while the three industries with the largest exports - machinery, chemical, and primary metals - account for almost 90 percent of both total export sales and growth in exports. The three industries with the largest output - food, chemical, and machinery - account for 75 percent of the total sales made between 1993 and 2000 and for 80 percent of the increase in sales.

Aggregate industry-level growth described in table 1 was generated by plant responses to changes in the economic environment that display a high degree of within-industry heterogeneity. Table 2 shows, by year, the percentage of plants in the sample that exit the market, the percentage of plants selling exclusively on the domestic market that begin exporting, the percentage exporting plants that stop exporting, and the percentages of exporting plants that increase and decrease their export sales by at least 25 percent. In all industries significant percentages of plants exit the market. Rates of exit are largest in 1995, the year of the domestic crisis. Between 1993 and 2000, textiles, wood, and glass industries lost roughly 15 percent of the plants, basic metals and machinery lost 9 percent, and the remaining industries lost around 6 percent of their plants. In all industries, exporting plants were much less likely to exit the market.

The number of exporting plants and export sales increased dramatically, but changes in the exporting status display heterogeneity both at the extensive margin and at the intensive margin. At all times and in all industries, there are both plants that enter the export market and, perhaps more surprisingly given the period when the favorable effects of NAFTA and exchange rate liberalization overlap, plants that exit the export market. All industries show the same temporal pattern: relatively larger percentages of plants start exporting and relatively smaller percentages stop exporting between 1993 and 1997 when the introduction of NAFTA and the exchange rate 
devaluation improved exporting conditions. The percentage of plants that start exporting in 19941995, the first year of NAFTA and the period when most plants initiated export operations, ranges from 5-7 percent in food, paper, and glass to 9-10 percent in chemical and machinery, to 15-18 percent in textiles and wood products. In 1997, when exchange rate rose, the percentage of plants that start exporting was lowest and the percentage of plants that stop exporting was largest in all industries.

Among exporters, there are, at all times, both plants that significantly lower their export value and plants that significantly increase their export levels. In all sectors, the shares of plants increasing their exports are larger in the years when the favorable effects of NAFTA and the low exchange rate overlap. The fraction of plants increasing their export values by at least 25 percent between 1994 and 1995 ranges between 60 percent in chemical and machinery industries and 82 percent in wood products. The share of plants reducing exports increased after the exchange rate returned to normal levels. Between 1999 and 2000 the fraction of plants reducing their exports by more than 25 percent ranges between 23 percent in machinery and 40 percent in wood products. In the last years of the panel the share of plants decreasing their exports was generally larger than the share of plants increasing their exports. Differences across sectors are largest in 1994-1995, when textiles, wood, and basic metals had the largest shares of plants increasing their exports.

\section{Total factor productivity}

Two problems must be addressed in estimating production functions with panel data sets. First, the correlation between input levels and unobserved productivity shocks induces simultaneity bias in the OLS estimation. Second, plants with low realizations of productivity exit the market. If plants with larger capital stock are more likely to survive negative realizations of productivity 
shocks, the OLS estimator of the capital coefficient will be biased. Several ways of dealing with these problems have been discussed in the literature. Olley and Pakes (1996) proposed a technique that allows corrections for both simultaneity bias and the selection bias introduced by non-random exits. A plant's investment function is modeled as a function of the capital stock capital and the productivity level unobserved by the econometrician. Under certain conditions, the investment function can be inverted, thus providing an instrument for the unobserved productivity component. The selection bias is corrected by formally modeling plants survival decisions and incorporating them into the estimation. Levinsohn and Petrin (2003) have proposed an approach to correct for the simultaneity bias that requires less-strict assumptions than those of Olley and Pakes (1996). They argue that investment responds only to the non-forecastable component of the productivity shocks and, therefore, the investment function does not perform well if the productivity term has both a serially correlated component and an idiosyncratic component. Instead, firm's intermediate input demand is used to obtain an instrument for the unobserved productivity shock. A number of recent papers (e.g. Pavcnik, 2002) have used this idea and employed a modified version of the Olley and Pakes (1996) approach in which the investment function was replaced by the intermediate input demand. Electricity provides the best instrument since few firms produce it and it cannot be stored. In this paper we use this later approach. The estimation procedure is described in the Appendix A.3.

Table 3 shows the estimation results using the two-step semiparametric method that accounts for the simultaneity and selection biases and, as a comparison benchmark, the results of standard, fixed-effects OLS estimation. We assume the production function of plant $i$ at time $t$ has a CobbDouglass form:

$$
y_{i t}=\alpha+\beta_{s} l_{i t}^{s}+\beta_{u} l_{i t}^{u}+\beta_{k} k_{i t}+\omega_{i t}+\varepsilon_{i t}
$$


where $y_{i t}$ is $\log$ value added, $l_{i t}^{s}$ is $\log$ of skilled labor, $l_{i t}^{u}$ is $\log$ of unskilled labor, $k_{i t}$ is $\log$ of plant's capital stock, $\omega_{i t}$ is the level of plant specific productivity, and $\varepsilon_{i t}$ is white noise. Production functions are estimated separately for the eight two-digit SIC manufacturing industries. The semiparametric estimation yields higher coefficients for capital and skilled labor and lower coefficients for unskilled labor. This finding is consistent with the presence of simultaneity bias: the use of easily adjustable factors, like unskilled labor, is positively correlated with productivity shocks, inducing upward bias of fixed effect estimates. The reverse is true for factors which are slow to adjust like skilled labor. Higher capital coefficients are consistent with the fact that large firms have a better chance to survive adverse productivity shocks. These results underscore the importance of controlling for both selection bias and simultaneity bias in the estimation of production functions.

Using the coefficient estimates, we construct two measures of plant productivity: total factor productivity $(T F P)$ defined as

$$
T F P_{i t}=y_{i t}-\hat{\beta}_{s} l_{i t}^{s}-\hat{\beta}_{u} l_{i t}^{u}-\hat{\beta}_{k} k_{i t}
$$

and a productivity index $(p r)$ defined as

$$
p r_{i t}=y_{i t}-\hat{\beta}_{s} l_{i t}^{s}-\hat{\beta}_{u} l_{i t}^{u}-\hat{\beta}_{k} k_{i t}-\left(y_{r}-\hat{y}_{r}\right)
$$

where $y_{r}=\bar{y}_{i r}, \hat{y}_{r}=\hat{\beta}_{s} \bar{l}_{i r}^{s}-\hat{\beta}_{u} \bar{l}_{i r}^{u}-\hat{\beta}_{k} \bar{k}_{i r}$ and $\bar{y}_{i r}, \bar{l}_{i r}^{s}, \bar{l}_{i r}^{u}, \bar{k}_{i r}$ are average industry values for a chosen base year $r$. The index (used, among others by Pavcnik, 2002) measures, for each plant, the distance from average industry practice in the base year. In this study we use 1993, the first year of our data, as the base year. We compute aggregate industry-level productivity $W_{t}$ as a weighted average of plant-level values of the productivity index, using plants' shares of industry output, $s_{i t}$, 
as weights.

$$
W_{t}=\sum_{i} s_{i t} p r_{i t}
$$

We decompose the aggregate productivity measure $W_{t}$, in two components: the average unweighted productivity measure $\overline{p r}_{t}=\frac{\sum_{i} p r_{i t}}{n}$ and a measure of the covariance between plants' output shares and productivity, which captures the extent to which industry's output is concentrated in more productive plants.

$$
W_{t}=\sum_{i} s_{i t} p r_{i t}=\overline{p r}_{t}+\sum_{i}\left(s_{i t}-\bar{s}_{t}\right)\left(p r_{i t}-\overline{p r}_{t}\right)
$$

This decomposition allows us to assess the extent to which aggregate productivity growth is due to plant-level efficiency gains or to concentration of market share at more productive plants. Higher concentration of industry output in more productive plants could, in turn, result from relatively faster productivity growth for larger plants or reallocation of market share from less to more productive plants. An individual plant's contributions to aggregate productivity and its components are, respectively, $s_{i t} p r_{i t}, \frac{p r_{i t}}{n}$, and $\left(s_{i t}-\bar{s}_{t}\right)\left(p r_{i t}-\overline{p r}_{t}\right)$. The total contributions of a subset A of an industry's plants are $\sum_{i \in A} s_{i t} p r_{i t}, \sum_{i \in A} \frac{p r_{i t}}{n}$, and $\sum_{i \in A}\left(s_{i t}-\bar{s}_{t}\right)\left(p r_{i t}-\overline{p r}_{t}\right)$.

Panel A in table 4 presents the aggregate productivity levels for the eight industries for each year. The positive values of aggregate productivity in 1993 for all but one sector indicate that plants that are more productive than average tend to produce larger shares of industry's output (1993 is the base year for computing the productivity index and therefore $\overline{p r}_{t}$ is zero in all sectors in 1993). Between 1993 and 2000 aggregate productivity increased in all sectors by values between 0.13 in wood products and 0.5 in machinery. Panels B and C show the unweighted average productivity, $\overline{p r}_{t}$, and the covariance components of aggregate productivity. The crisis of 1995 is clearly marked 
by sharp drops in $\overline{p r}_{t}$ in all sectors. After $1995, \overline{p r}_{t}$ raises in most sectors, but over the entire period increases in only five out of the eight sectors and gains are modest in most sectors. In textiles, wood products, chemical industry $\overline{p r}_{t}$ declined between 1993 and 2000, in food products and machinery show modest increases in productivity (around 7\%), while paper products, glass, and primary metals show increases of $15-30$ percent in their average productivity.

In all sectors, the covariance component represents the largest share of aggregate productivity, which means that industry output tends to be strongly concentrated in most productive plants. Further concentration of industry's output through reallocation of market share from less productive to more productive firms is the dominant mechanism for industry productivity gains - with the exception of basic metals, the growth of covariance component between 1993 and 2000 far exceeds the growth of the unweighted productivity component for all industries.

\section{Responses to changes in the economic environment and contributions to aggregate productivity growth}

The aggregate productivity growth and the relative importance of the covariance component are common findings in studies of trade liberalization episodes or periods of declining trade costs. Previous literature shows that the basis of the trade-induced aggregate productivity growth is the correlation between plants' productivity and plants' output performance. Among plants selling exclusively on the domestic market before trade liberalization, the least productive contract or exit the market and the more productive expand by entering export market, while plants that exported before trade liberalization increase their export sales. Exit of the least productive plants raises the unweighted component of aggregate productivity, but to the extent to which they produce 
relatively smaller shares of output, it reduces the covariance component, and therefore the overall effect on aggregate productivity could be either positive or negative. Among the surviving plants, the reallocation of output from less to more productive leads to an increase in the covariance component and therefore industry productivity growth.

The heterogeneity of plants' exporting performance - the simultaneous entry into and exit from the export market and the large changes in the export sales of continuing exporters - suggests, however, that the magnitude of the contributions to aggregate productivity growth may differ significantly among plants that take advantage of NAFTA to enter export markets and among plants that exported before the introduction of NAFTA. It also leaves open the possibility that the nature of these contributions is different from that suggested by previous literature, namely gains in market share by most productive plants that start or intensify exports, and includes plant-level productivity gains by a subset of exporting plants.

In this section we analyze the contributions to the aggregate productivity of plants with different types of responses to the changes the economic environment. First, we study plants that exit the market between 1993 and 2000. Second, for plants in the balanced panel, we use principal component analysis to study the intra-industry variation in the joint productivity and output performance, the determinants of plants contributions to aggregate productivity. We then use the results of the principal component analysis to analyze the contributions to aggregate productivity growth of plants with different types of exporting experience between 1993 and 2000.

\subsection{Plants that exit the market}

Of the total number of plants we observe, 10 percent exit the market between 1993 and 2000; by sector, percentages vary from 4 percent in paper products to 17 percent in textiles, wood products, 
and glass. Most of the exits take place in 1995, the year of the domestic crisis, and with only few exceptions they are selected among plants that sell exclusively on the domestic market. In panel A of Table 5, we compare the average productivity and output of plants that exit with the average productivity and output of surviving plants, during the period before exit. Entries in the table represent the number of exiting plants, the difference between the average productivity of exiting and surviving plants, and the average output of exiting plants as a percentage of the average output of surviving plants, by industry and years before exit. In all sectors, plants that exit are both smaller and less productive than surviving plants. Both average productivity and output are lower long before the actual exit. Exit from the market is preceded by a period in which both output and productivity decline.

Panel B shows the contribution of plants that exit the market to the unweighted productivity and the covariance components of aggregate productivity growth. Since plants that exit are less productive than those that survive, their exit contributes to the growth of the average unweighted productivity, $\overline{p r}_{t}$. The contribution of plants that exit to the covariance component, before the actual exit, is positive, since they account for relatively smaller shares of industry output. Their exit, reduces the covariance of productivity and output shares and lowers the aggregate productivity. The contributions of plants that exit to the two components of aggregate productivity are of comparable magnitudes, and therefore the total effect of exits on aggregate industry-level total factor productivity is very small. 


\subsection{Plants in the balanced panel}

\subsubsection{Principal Component Analysis}

For plants in the balanced panel, we use principal component analysis (PCA) to study the withinindustry variation in the joint output and productivity performance. ${ }^{10}$ In the PCA framework, data on plant-level total factor productivity and output are regarded as curves or equispaced vectors. Each plant in the balanced panel is characterized by two vectors: $X_{Y}^{i}(t)$ describes plant $i$ 's output $(Y)$ at time $t$ and $X_{P}^{i}(t)$ describes plant $i$ 's total factor productivity $(P)$ at time $t$, where $i=$ $1, \ldots, N, t=1, \ldots, T$. The $1 \times 2 T$ vector $X^{i \prime}=\left[X_{Y}^{i \prime} \mid X_{P}^{i \prime}\right]$, where $X_{Y}^{i \prime}=\left[X_{Y}^{i}(1)|\ldots| X_{Y}^{i}(T)\right]$ and $X_{P}^{i \prime}=\left[X_{P}^{i}(1)|\ldots| X_{P}^{i}(T)\right]$, represents the joint output and productivity performance for plant $i$.

The collection of heterogeneous output and productivity performances of plants in an industry can be summarized in terms of the industry-level average vectors $\bar{X}^{i \prime}=\left[\bar{X}_{Y}^{i \prime} \mid \bar{X}_{P}^{i \prime}\right]$ and the $2 T \times 2 T$ correlation matrix $\Gamma=\left[\begin{array}{cc}\operatorname{Corr}\left(X_{Y}^{i}, X_{Y}^{i}\right) & \operatorname{Corr}\left(X_{Y}^{i}, X_{p}^{i}\right) \\ \operatorname{Corr}\left(X_{Y}^{i}, X_{p}^{i}\right) & \operatorname{Corr}\left(X_{p}^{i}, X_{p}^{i}\right)\end{array}\right]$ which measures the variation of the plant-level vectors about this average.

The correlation matrix, symmetric and positive semi-definite, is decomposed in terms of its latent roots (eigenvalues) and latent vectors (eigenvectors), $\Gamma=\sum_{j} \lambda_{j} \phi_{j} \phi_{j}^{\prime}$, where $\lambda_{j}, j=1, \ldots, J$, $J=\operatorname{rank}(\Gamma)$, are real, non-negative eigenvalues and $\phi_{j}$ are $J$ orthogonal eigenvectors normalized so that $\phi_{j}^{\prime} \phi_{j}=\lambda_{j}$. The original data set is recast in terms of a set of $J$ principal components (PCs), $\xi_{j}=X^{i} * \phi_{j}$, which are uncorrelated standard normal random variables, linear combinations of the original variables. As eigenvalues decline fast, the first few PCs capture most of the variation in the original data.

Plant $i$ 's output and productivity performance can be decomposed into the industry average,

\footnotetext{
${ }^{10}$ Ramsay (1982), Rice and Silverman (1991), Jones and Rice (1992) used principal component analysis to identify and study modes of variation in collections of curves.
} 
$\bar{X}^{i \prime}$, and a sum of orthogonal curves - the eigenvectors $\phi_{j}$ - with uncorrelated amplitudes given by the plant's values corresponding to the $J$ PCs $\xi_{j}$.

$$
X^{i \prime}=\bar{X}^{i \prime}+\left(\sum_{j} \xi_{j} \phi_{j}^{\prime}\right) * \sigma, \text { where } \sigma \text { is a } 2 T \times 2 T \text { matrix with the standard deviations } X^{i} \text { on }
$$
the main diagonal and zeros elsewhere. The eigenvectors capture the modes in which output and productivity performance in an industry varies around the industry average and the values of the PCs corresponding to each plant show how far the plant is from the industry average along the respective modes of variation.

Table 6 shows, by industry, the eigenvectors corresponding to the largest three eigenvalues and the percentage of the total variance explained by the first three PCs. The first three PCs explain between 80 and 90 percent of the total variance, and the modes of variation they describe are remarkably similar across sectors. The first component alone explains between 49 percent and 68 percent of the total variance. The interpretation of the mode of variation captured by the first PC is the following. Plants with large values of the first PC were larger and more productive than average in 1993 and both their productivity and output grew between 1993 and 2000. At the other end of the spectrum, plants with small values of the first PC were smaller than average and less productive in 1993 and between 1993 and 2000 they contracted and became less productive. Individually, the second and the third PCs explain lower shares of the total variance. Plants with large values for the second PC were larger than average but less productive in 1993 and they tended to have larger temporary declines in productivity around 1995 and 1996, those with small values were smaller than average but more productive. The third PC ranks plants by their productivity growth irrespective of their output levels - plants with large values were less productive than average in 1993 and experience strong productivity growth, plants with small values were more productive than average in 1993 their productivity declined. 


\subsubsection{The magnitude and nature of plants contributions to aggregate productivity}

We use the values of the first PC as an index of plants' contributions to aggregate productivity. Not only does the first PC explain a large share of the total variation in plants' joint output and productivity performance, but also provides an accurate characterization of both the magnitude and the nature of plants' contributions to the growth of both components of the aggregate productivity index. To illustrate this point, in table 7 we show how the productivity and output performance, as well as the contributions to aggregate productivity vary across the values of the first PC. We present the performance of plants in the first (bottom) and tenth (top) deciles of the first PC and compare them with the performance of all plants in the balanced panel. Columns (1) to (4) show large intra-industry heterogeneity of plant-level productivity and output performance. In all but one sector, the average total factor productivity in 1993 of plants in the tenth decile (largest values of the first PC) was much larger than the industry average (column 2) and their average output was 4 to 7 times larger than the industry average (column 3). On the other hand, plants in the first decile (smallest values of the first PC) were much smaller and less productive than the industry average. In all sectors, between 1993 and 2000 the average total factor productivity of plants in the tenth decile grew significantly, while that of plants in the first decile declined (column 2). Between 1993 and 2000 average output of plants in the tenth decile grew between 35 and 100 percent, while average output of plants in the first decile declined in six sectors and saw single digit growth rates in two sectors. In five of the eight sectors (food, textiles, wood, metals, and machinery) average output of plants in the top decile grew faster than the industry average, which is surprising given how much larger these plants were in 1993. Columns (5) and (6) show that plants in the top decile of the first PC account for 40 to 70 percent of total output produced between 1993 and 2000 and for 45 to 80 percent of the output growth. 
Columns (7) to (12) show the sum of the contributions to aggregate productivity, its components, and their growth of plants in the top and bottom deciles of the first PC, compared with the overall contributions of all plants in the balanced panel. Plants in the first decile drive down the unweighted average productivity (column 7), but since they produce small shares of industry's output, they have positive contributions to the covariance component. Their productivity declines and therefore their contributions to the growth of the unweighted component are negative, but they also contract, which translates into positive contributions to the growth of the covariance component. The negative contributions to the unweighted average productivity component and the positive contributions to the covariance component are of similar magnitudes and, therefore, contributions to the aggregate productivity growth of plants in the first decile are very small. On the other hand, plants in the tenth decile account for roughly two thirds of the aggregate productivity growth (by sector shares vary between 38 percent in paper products and 87 percent in machinery). In all sectors, plants in the top decile have positive contributions to the unweighted average productivity component and its growth and to the covariance component and its growth, since they were larger and more productive in 1993 and both their average productivity and output grew between 1993 and 2000.

\subsubsection{Export status and performance}

The intra-industry heterogeneity in plants' productivity and output performance and concentration of output and aggregate productivity growth, on the one hand, and the sector-level heterogeneity industries with large degrees of concentration (like machinery) account for large shares of the overall manufacturing output and output growth - on the other hand, imply, when considered together, that most gains accrue to a small number of manufacturing plants. To analyze the way in which this extraordinary plant-level performance of a small number of plants is related to exporting, we 
consider two dimensions of exporting activity. The first one is plant's export status in 1993, before the implementation of NAFTA. Second, we create a dynamic export status variable that describes plants' exporting experience between 1993 and 2000. The dynamic export status variable takes into account the high incidence of movements into and out of the export market as well as the temporal patterns displayed by these movements. We construct six types for exporting activity: a) plants that never export (never), b) plants that always export (always), c) plants that have two or more spells of exporting during this period (multiple) and three categories of plants that have one spell of exporting that lasts less than the entire period - d) plants that export in 1993 but stop exporting before 2000 (stop), e) plants that start exporting after the implementation of NAFTA and export continuously until 2000 (begin), and f) plants that start exporting after 1993 and stop exporting before 2000 (temporary). These categories allow us to distinguish, albeit imperfectly, ${ }^{11}$ among plants that exit the export market, plants that took advantage of NAFTA to become exporters, and plants that needed the added effects of NAFTA and exchange rate devaluation to export part of their output temporarily. For plants with different types of exporting activity, we compare their productivity and output in 1993, productivity and output growth between 1993 and 2000, and joint productivity and output performance as described by the first PC.

Table 8 shows the coefficients of simple, sector-level linear regressions with productivity and output in 1993, and productivity and output growth between 1993 and 2000 as dependent variables and exporting status in 1993, on the one hand, and the dynamic exporting status, on the other hand, as independent variables. We present only the coefficients that are significant at $90 \%$ level of confidence. In 1993, before the implementation of NAFTA, exporting plants were larger but not

\footnotetext{
${ }^{11}$ We recognize that the distinction we draw here between plants with different dynamic export status is dependent on the relatively short time span of the panel. This classification is simply a convenient description of the eight-year segment of plants' exporting history that we observed in the data set.
} 
more productive than non-exporting plants. The coefficients in column (2) in the regression with output in 1993 as dependent variable are positive and significant in all but one sector, glass. The coefficients in the regression with productivity in 1993 as dependent variable were not significant, with the exception of one sector, basic metals, where exporting plants were less productive. In five out of eight sectors (food, textiles, paper, chemical, and machinery), output growth between 1993 and 2000 was significantly larger at plants that exported before the implementation of NAFTA, while total factor productivity growth was not significantly different (with the only exception of basic metals industry).

When we compare coefficients in the regressions with output in 1993 as dependent variable across specifications, three patterns emerge. First, the magnitudes of the coefficients corresponding to plants that always export in column (8) are larger than those in column (2) which shows that plants that always export (always) are selected among the largest 1993 exporters. Second, the magnitudes of the constant terms in column (3) are smaller than those in column (1) indicating that plants that never export (never) are selected among the smaller 1993 non-exporters. Third, in four sectors (food, textiles chemical, glass), plants that began exporting after NAFTA and export continuously until 2000 (begin) are selected among the larger 1993 non-exporters, while plants with other types of exporting experience (stop, temporary, and multiple) are not significantly larger than those that never export.

Among plants with different types of exporting experience, again, only plants that always export have consistently and significantly larger output growth than plants that never export. Results with respect to productivity remain weak even when we account for movements into and out of the export market. Neither productivity in 1993 nor productivity growth between 1993 and 2000 of plants with different types of exporting experience are significantly higher than those of plants 
that never export.

We analyze two aspects of the relationship between plants' exporting activities and their joint productivity and output performance. First, we analyze the makeup of the groups of plants with best and, respectively, worst output and productivity performance, i.e., the probability distribution of the types of exporting activity conditional on the values of the first PC. Second, we estimate an ordered probit model to analyze how the probability of being in each one of the ten deciles of the first $\mathrm{PC}$ is associated with the type of exporting activity, i.e., the probability distribution of the values of the first PC, conditional on the type of exporting activity.

Table 9 shows, by industry, the distributions of plants with different dynamic exporting status in the balanced panel and in the first and the tenth deciles of the first PC. While plants that exported before NAFTA and export continuously through 2000 (always) represent larger fractions of top-performing plants, the performance of plants with similar exporting experience displays remarkable heterogeneity. In all industries, plants that never export (never) represent significant shares of top-performing plants while many exporting plants display poor performance. In five of the eight sectors plants that always export represent the largest share of plants in the top decile of the first PC (62 percent in machinery, 61 percent in chemical, 54 percent in textiles, 42 percent in wood products, and 40 percent in the primary metals sector). In three sectors, plants that never export represent the largest share of the top performers (42 percent in food products, 37 percent in glass, and 26 percent in paper products). Plants that begin exporting after 1993 and export continuously until 2000 (begin) represent the second largest share of top performing plants in six of the eight sectors. In seven of the eight sectors (the exception is basic metals) plants that never export represent the largest shares of the plants in the first decile of the first $\mathrm{PC}$ - plants with poor output and productivity performance. Plants that always export, however, represent significant 
shares of the plants in the first decile in all but two sectors (wood and paper products). Plants with other types of exporting activity are also found among the worst performing plants in shares comparable to their share of the balanced panel sample.

Table 10 shows the estimation results for an ordered probit model with deciles of the first PC as dependent variable and plants' dynamic exporting status, share of skilled labor, share of imported inputs, capital intensity, and a binary variable that indicates foreign direct investment in 1993. In six out of eight sectors (food, textiles, wood, paper, chemicals, and machinery) the coefficients for plants that always export are positive and significant indicating these plants are more likely to be found among the plants with better output and productivity performance than plants that never export. In six of the eight sectors (food, textiles, wood, paper, chemicals, and glass) the coefficients for plants that begin exporting after 1993 and export continuously until 2000 (begin) are positive and significant. Controlling for exporting status, capital intensity, foreign direct investment, and the use of imported inputs are positively correlated with output and productivity performance. Both the use of imported inputs and foreign direct investment have positive and significant coefficients in food, chemicals, and machinery sectors, the three sectors with the largest output growth.

Using the estimates from the ordered probit model, we construct the average probabilities of being in each of the 10 deciles of the first PC, by plants' dynamic exporting status. Figure 1 shows the probability profiles by industry. The slope of the probability profile measures the heterogeneity of the performance of plants with a certain type of exporting activity. Flat profiles - uniform probability distribution across the deciles of the first PC - indicate a high degree of heterogeneity; higher positive (negative) slopes indicate relatively higher likelihood of superior (poor) output and productivity performance. Two patterns emerge from the eight panels. First, in all sectors, the probability profiles of plants with most types of exporting status fall within a narrow band (0.05 - 
0.15 probability), which indicates that productivity and ouptut performance of plants with similar types of exporting activity display strong heterogeneity. Second, plants with two types of exporting activity depart consistently from this pattern: plants that always export are relatively more likely to be found among the plants in the top decile and plants that exported in 1993 but stopped exporting (stop) are relatively more likely to be found in the bottom decile.

The heterogeneous performance of plants with similar exporting activity implies that the reduction in the costs of trade provided growth opportunity to larger and more productive plants irrespective of their export status. The success of plants that sell exclusively on the domestic market can have several explanations. The export-driven aggregate growth led to higher incomes and higher domestic demand, which must have played an important role in sectors like food, paper, and glass. Higher exports also meant higher demand for intermediary inputs produced by domestic plants in upstream industries. Finally, stronger import competition forced domestic plants to take steps to improve their productivity, and plants which were larger and more productive in 1993 were better positioned to implement efficiency enhancing measures.

While a subset of the exporting plants perform very well, the heterogeneous performance of plants with similar exporting activity provides an explanation why on average the productivity performance of exporting plants is not better than that of plants that never export. Several explanations could account for the poor performance of exporting plants during a period in which NAFTA and the exchange rate devaluation provided favorable exporting conditions. A fair amount of heterogeneity in the performance of exporting plants could probably be explained by purely idiosyncratic factors. A portion could also be due to the life cycle of the products - as products become obsolete, foreign demand declines forcing exporting plants to contract or exit the export market. Finally, large sunk costs of exporting could create hysteresis of exporting activity. Exporting plants 
may prefer to incur temporary losses resulting from a decline in demand for their products rather than exit the foreign markets. Trade liberalization may mitigate this hysteresis effect. It may also attract more productive infra-marginal plants into exporting, thus shrinking the market for some of the less productive incumbents and forcing them to contract or exit the foreign market altogether.

\section{Conclusion}

We use panel data on Mexican manufacturing plants to study the relationship between plants' responses to changes in the economic environment and their contributions to aggregate productivity growth in the period following the implementation of NAFTA. Many of our results are consistent with previous literature on the effect of NAFTA on the performance of the Mexican economy and with the broader literature on the connection between trade and plant-level and industrylevel performance. Our data show intense export-driven growth in aggregate performance between 1993 and 2000 - the number of exporting plants in the sample grew by almost 50 percent, export sales doubled, and domestic sales rose by 32 percent. The underlying plant-level behavior displays remarkable heterogeneity. Some plants contract or exit the market. Others expand by taking advantage of lower costs of trade to enter export markets or to increase export sales. Changes in the export activity are heterogeneous both at the extensive margin - plants constantly enter and exit export markets - and at the intensive margin - exporters increase and decrease export sales by significant margins. Patterns of entries and exit and changes in intensity depend on the economic conditions - entries into the export market and increases in exporting intensity are relatively more prevalent in the period when the effect of NAFTA and the exchange rate devaluation overlap - and vary across industries.

The complementary changes in export status and changes in export intensity, as well as the 
simultaneity of entries into and exits from the export market and of intensification and reduction in exporting activity have been discussed in previous literature. Bernard and Jensen (2004), find that 60 percent of the export growth is due to changes in exporting intensity at existing exporters, while Bernard and Jensen (1999) find that 15 percent of today's exporters will stop exporting next year and 10 percent of non-exporters will enter foreign markets. What we find more surprising is how intense exits from the export market and reductions in the exporting intensity remain even during periods of very favorable exporting conditions. In this respect, our results are consistent with those in Blalock and Roy (2007), who find that a 2 to 1 devaluation in Indonesian rupiah caused substantial exit from the export market, exit large enough to offset the growth of exports at existing exporters and new entries.

Aggregate, industry-level total factor productivity has grown in all industries driven to a large extent by reallocation of output from the less to more productive plants. Previous literature has identified international trade - a catalyst of the reallocation process - as a major determinant of the aggregate productivity growth. In industries with heterogeneous plants and sunk costs of exporting, more productive plants self-select into exporting; a reduction in the costs of exporting forces least productive plants in the industry to exit the market, most productive non-exporting plants to enter export markets, and existing exporters to expand. Our results suggest a picture that differs in several important respects from these theoretical predictions. First, plant deaths contribute little to aggregate productivity growth. Plants that exit the market are selected among the least productive non-exporting plants, but their contributions to the unweighted average productivity component and to the covariance component are of opposite signs and similar magnitudes. Plants that exit the market are less productive than the surviving plants long before the actual exit. The "shadow of death," the relatively long period of contraction preceding exit from the market, makes 
the actual exit an event of little consequence to the aggregate industry performance.

Second, we find no evidence that plants that exported in 1993 were, on average, more productive than those that did not export and no evidence that plants with strong exporting performance between 1993 and 2000 were more productive in 1993 than those that never export in this period. Plants that exported in 1993, especially those that continued to export until 2000, were larger to begin with and grew more than those that did not export, but since they were not, on average, more productive, their expansion could not lead to aggregate productivity growth.

Finally, we do find that strong exporting activity is associated with productivity growth at plant level, but this connection is shaped by strong plant-level heterogeneity. Aggregate productivity growth is concentrated in a small fraction of plants. These plants were larger and more productive in 1993, they grew faster, and, more importantly, became more productive between 1993 and 2000. The group of top-performing plants is very diverse - plants that exported in 1993 and export continuously through 2000, new entrants into the export market, but also a significant number of plants that never export - and the distribution of performance is remarkably uniform within the sets of plants with similar exporting activity. However, plants that export continuously between 1993 and 2000 and new entrants that export continuously through 2000 have consistently higher probability of being among the top-performing group than plants that never export. Other than exporting activity, we found that two factors related to integration into global markets are consistently correlated with strong output and productivity performance: the use of imported inputs and foreign investment.

These findings can be rationalized in the context of existing models of exporting decisions. If there are significant sunk costs of exporting and if returns from exporting are uncertain, then large plants may be better able to absorb the sunk costs and incur the risks associated with entry 
into the foreign markets than smaller plants, even very productive ones. Exporting plants, on the other hand, may find it optimal to accept temporary losses generated by unexpected declines in foreign demand, rather than exit the export markets. This hysteresis effect implies that, at any given point in time, many current exporters may be less productive than current non-exporting plants and that among plants that remain in the export market the dynamics of the performance is very heterogeneous. The reduction in the costs of trade does not guarantee good performance for all exporting plants. Trade liberalization reduces the sunk costs of exporting. More productive infra-marginal plants begin exporting, reducing the market share of less productive incumbents and forcing them to contract. Lower foreign demand and lower opportunity costs of exiting the foreign markets induce least productive exporters to cease exporting.

The strong output and productivity growth following the introduction and NAFTA, the existence of plant-level productivity gains, and the fact that these gains are correlated with exporting activity, foreign investment, and use of imported inputs suggest that NAFTA has achieved its goals, and that integration into global markets, in general, helps plants move closer to the international productivity frontier. The concentration of output and productivity gains in a relatively small number of plants and the association between foreign investment and use of imported inputs and plant-level performance indicate that a significant share of the gains from NAFTA accrue to foreign-owned factors of production.

\section{$7 \quad$ References}

Bernard, A., Eaton, J., Jensen, J. B., and Kortum, S. (2003) "Plants and Productivity in International Trade," American Economic Review 93, 1268-1290.

Bernard, A., Jensen, J. B. (1999) "Exceptional exporters performance: cause, effect or both?" 
Journal of International Economics 47, 1-25.

Bernard, A., Jensen, J. B. (2004) "Why Some Firms Export?" The Review of Economics and Statistics 86, 561-569.

Bernard, A., Jensen J. B, and Schott, P. K. (2006) "Trade Costs, Firms, and Productivity" Journal of Monetary Economics 53, 917-937.

Blalock , G. and Roy, S. (2007) "A firm level examination of theexports puzzlewhy East-Asian exports did not increase after 1997-1998 financial crisis," The World Economy 30, 39-59.

Greenway, D. and Richard, K. (2007) "Firm Heterogeneity, Exporting and Foreign Direct Investment," The Economic Journal 117, 134-161.

Helpman, E., Melitz, M. and Yeaple, S. (2004) "Export versus FDI," American Economic Review 94, 300-316.

Jones, M. C. and Rice, J. A. (1992) "Displaying the Important Features of Large Collections of Similar Curves," The American Statistician 46, 140-145.

Lederman, D., Maloney, W., Serven, L. (2003) "Lessons form NAFTA for Latin American and Caribbean (LAC) Countries: A Summary of Research Findings," World Bank.

Levinsohn, J. and Petrin, A. (2003) "Estimating Production Functions Using Inputs to Control For Unobservables," Review of Economic Studies 70, 317-341.

Lopez-Cordova, E. (2002) "NAFTA and Mexico's Manufacturing Productivity: An Empirical Investigation Using Micro-level Data," mimeo, Inter-American Development Bank, Washington, D.C.

Melitz, M. J. (2003) "The Impact of Trade on Intra-Industry Reallocations and Aggregate Industry Productivity," Econometrica 71, 1695-1725.

Olley, S. and Pakes, A. (1996) "The Dynamics of Productivity in the Telecommunications 
equipment Industry," Econometrica 64, 1363-1298.

Pavnick, N. (2002) "Trade Liberalization, Exit, and Productivity Improvements: Evidence from Chilean Plants," Review of Economic Studies 69, 245-276.

Ramsay, J. O.(1982) "When the Data are Functions," Psychometrika 47, 379-396.

Rice, J. A. and Silverman B.W. (1991) "Estimating the Mean and Covariance Structure Nonparametrically When the Data are Curves," Journal of the Royal Statistical Society, Series B, 53, 233-243.

Schiff, M. and Wang, Y. (2003) "Regional Integration and Technology Diffusion: The Case of the North America Free Trade Agreement," World Bank Policy Research Working Paper No. 3132.

Tybout, J. R. (2003) "Plant and firm level evidence on new trade theories," in (E. Kwan Choi and J. Harrigan, eds.), Handbook of International Economics, 388-415, Oxford: Blackwell.

Tybout, J. and Westbrook, M.D. (1995) "Trade Liberalization and the Dimensions of Efficiency Change in Mexican Manufacturing Industries," Journal of International Economics 39, 53-78.

Yeaple S. R. (2003) "Firm Heterogeneity, International Trade, and Wages," University of Pennsylvania mimeo. 


\section{Appendix}

\section{A.1. Annual Industrial Survey}

AIS uses a non-probabilistic sample drawn from the universe of manufacturing establishments provided by the 1993 Industrial Census. The sample was selected according to the following two criteria. First, two types of plants were excluded from the sample: establishments that operate under the special maquiladora regime and petrochemical and oil-refining plants which are state-owned monopoly. Second, 205 six-digit industries with the largest contribution to total manufacturing production were selected from a total of 309 six-digit industries. ${ }^{12}$ The largest plants from each industry, covering at least $80 \%$ of the total value of gross production of the industry, were included in the sample. All remaining plants with at least 100 employees were added to the sample. In classes where production was highly concentrated, all establishments were included, whereas in classes with highly disaggregated production maximum 100 establishments were included in the sample. As a result, the AIS sample includes all the largest plants in the population and a significant share of medium-scale plants, but a smaller share of small plants and very few micro-enterprises. The AIS sample has not been refreshed since 1993, but its composition changed every year. Plants were excluded from the sample for a number of reasons among which, plant closings are well identified. Plants were added to the sample every year to replace the plants lost.

\section{A.2. Imputation of capital stock}

Capital stock is imputed using perpetual inventory method. The replacement value of capital stock provided by IC is the basis of the imputation procedure. Plants in the data set can be classified in three categories: plants present in both IC 1993 and IC 1998, plants present in IC 1993 which

\footnotetext{
${ }^{12}$ Establishments are classified according to the Mexican Classification of Activities and Products, which at a 4-digit level is compatible with the International Uniform Industrial Classification.
} 
exit the sample before 1998, and plants which enter the sample between 1993 and 1998, present only in IC 1998. For all plants which were in present in IC 1993 we impute capital stock using the replacement value of capital stock in IC 1993 as a basis. For plants which were present in both IC 1993 and IC 1998, we compare the imputed value of capital stock in 1998 with the value of capital stock in IC 1998 to obtain deflators for each of the seven types of capital stock. Finally, for plants which initiated operations between 1993 and 1998, and were therefore present only in IC 1998, we impute capital stock by using the replacement value of capital in IC 1998, appropriately deflated, as basis.

The second ingredient of the imputation procedure is the rate of depreciation of the capital stock. We use IC 1998 information on capital stock, investment, sales of capital, and depreciation to calculate depreciation rates for five types of capital (excluding land), for 70 five-digit manufacturing sectors. For each firm we calculate depreciation rates for the five types of capital, then median rates for each of the five-digit sector are chosen. In calculating depreciation rates, it is important to consider the distribution of investments and sales of capital during the year. The precise timing of the investments taking place during one year is generally not known and assumptions are necessary (for example, one can assume that all investments take place at the beginning of the year, at the end of the year or are uniformly distributed during the year). The assumed timing of the investments determines the denominator of the depreciation rate and, hence, the size of the depreciation rate. In this paper we assume both investments and sales of capital are uniformly distributed during the year.

Investments and sales of capital are the third ingredient of the imputation procedure. From AIS we extracted information on investments for two groups of capital stock types. First group pools together machinery, transportation equipment, computing and peripheral equipment, and furniture 
and office equipment, the second group contains and buildings and land. The first group is further divided into domestic and imported capital goods. For each of these three types of investment we use deflators constructed by Banco de Mexico.

The perpetual inventory method is applied to each type of capital. The total capital stock is computed by summing the values for the six types and an imputed value of the rented buildings obtained by multiplying annual rent by 10 . Capital stocks at the beginning and at the end of the year were calculated. In the estimation we use the average capital stock in a given year.

\section{A.3. Estimation of the production function}

We estimate industry-specific production functions using a modified version of the approach introduced by Olley and Pakes (1996) in which the investment function is replaced by intermediate input demand. In this paper we use demand for electricity which, arguably, provides the best instrument since few firms produce electricity and electricity cannot be stored.

Consider the production function of firm at time t:

$$
y_{i t}=\alpha+\beta_{s} l_{i t}^{s}+\beta_{u} l_{i t}^{u}+\beta_{k} k_{i t}+\omega_{i t}+\varepsilon_{i t}
$$

where $y_{i t}$ is $\log$ value added, ${ }_{s} l_{i t}^{s}$ is log of skilled labor, $l_{i t}^{u}$ is log of unskilled labor, $k_{i t}$ is $\log$ of plant's capital stock, $\omega_{i t}$ is the level of plant specific productivity, and $\varepsilon_{i t}$ is white noise. A firm's private knowledge of $\omega_{i t}$ plays a role in both exit and input choice decisions. Firm's demand for electricity is:

$$
e_{i t}=e_{i t}\left(\omega_{i t}, k_{i t}\right)
$$


Under monotonicity conditions, the demand function can be inverted,

$$
\omega_{i t}=\omega_{i t}\left(e_{i t}, k_{i t}\right)
$$

Replacing $\omega_{i t},(1)$ becomes:

$$
y_{i t}=\beta_{s} l_{i t}^{s}+\beta_{u} l_{i t}^{u}+\phi\left(e_{i t}, k_{i t}\right)+\varepsilon_{i t}
$$

where $\phi\left(e_{i t}, k_{i t}\right)=\alpha+\beta_{k} k_{i t}+\omega_{i t}$

In the first step we use OLS to estimate $\hat{\beta}_{s}$ and $\hat{\beta}_{u}$ in $(2)$ where $\phi\left(e_{i t}, k_{i t}\right)$ is represented by a polynomial expansion in $e_{i t}$ and $k_{i t}$. Using the coefficient estimates at the first step, we calculate an estimate for $\phi\left(e_{i t}, k_{i t}\right), \hat{\phi}\left(e_{i t}, k_{i t}\right)=y_{i t}-\hat{\beta}_{s} l_{i t}^{s}-\hat{\beta}_{u} l_{i t}^{u}$

Let

$$
y_{i t+1}^{*}=y_{i t+1}-\beta_{s} l_{i t+1}^{s}-\beta_{u} l_{i t+1}^{u}=\alpha+\beta_{k} k_{i t+1}+\omega_{i t+1}+\varepsilon_{i t+1}
$$

To address the selection bias problem, firm's exit decision is specifically modelled. Writing the realization of the new productivity shock as a sum of a forecasted component and an idiosyncratic component, $\omega_{i t+1}=E\left[\omega_{i t+1} \mid \omega_{i t}\right]+\eta_{i t+1}$, and denoting $g\left(\omega_{i t}\right)=\alpha+E\left[\omega_{i t+1} \mid \omega_{i t}\right]$, equation 3 becomes

$$
y_{i t+1}^{*}=\beta_{k} k_{i t+1}+g\left(\omega_{i t}\right)+\varepsilon_{i t+1}
$$

A firm is observed only if the realization of productivity is above a certain threshold. The firms 
exit decision is then represented by:

$$
\begin{aligned}
& X_{t}=1 \text { if } \omega_{t}>\underline{\omega_{t}} \\
& X_{t}=0 \text { otherwise }
\end{aligned}
$$

Incorporating the exit decision, (3) becomes:

$$
\begin{aligned}
y_{i t+1}^{*} & =y_{i t+1}-\beta_{s} l_{i t+1}^{s}-\beta_{u} l_{i t+1}^{u}= \\
& =\alpha+\beta_{k} k_{i t+1}+E\left[\omega_{i t+1} \mid \omega_{i t}, \omega_{t+1}>\underline{\omega_{t+1}}\right]+\eta_{i t+1}+\varepsilon_{i t+1}
\end{aligned}
$$

The second estimation step is then:

$$
\begin{aligned}
& y_{i t+1}^{*}=y_{i t+1}-\hat{\beta}_{s} l_{i t+1}^{s}-\hat{\beta}_{u} l_{i t+1}^{u}= \\
&=\beta_{k} k_{i t+1}+g\left(\hat{\phi}\left(e_{i t}, k_{i t}\right)-\beta_{k} k_{i t}, \hat{P}_{i t}\right)+\eta_{i t+1}+\varepsilon_{i t+1}
\end{aligned}
$$

We use a polynomial expansion for $g$,

$g\left(\hat{\phi}\left(e_{i t}, k_{i t}\right)-\beta_{k} k_{i t}, \hat{P}_{i t}\right)=\sum_{j} \sum_{l} \beta_{j l}\left(\hat{\phi}\left(e_{i t}, k_{i t}\right)-\beta_{k} k_{i t}\right)^{j} \hat{P}_{i t}^{l}$ and non-linear least square to estimate (4).

Finally, using the coefficient estimates from the two steps of the estimation, we calculate total factor productivity as

$$
\hat{\omega}_{i t}=y_{i t}-\hat{\beta}_{s} l_{i t}^{s}-\hat{\beta}_{u} l_{i t}^{u}-\hat{\beta}_{k} k_{i t}
$$


Table 1. Total, domestic, and export sales by industry, $1993-2000$

\begin{tabular}{|c|c|c|c|c|c|c|c|c|c|c|c|c|c|c|c|c|c|c|c|}
\hline \multicolumn{2}{|l|}{ Sector } & \multicolumn{2}{|c|}{1993} & \multicolumn{2}{|c|}{1994} & \multicolumn{2}{|c|}{1995} & \multicolumn{2}{|c|}{1996} & \multicolumn{2}{|c|}{1997} & \multicolumn{2}{|c|}{1998} & \multicolumn{2}{|c|}{1999} & \multicolumn{2}{|c|}{2000} & \multicolumn{2}{|c|}{$1993-2000$} \\
\hline & & & & & & & & & & & & & & & & & & Char & ge (\%) \\
\hline \multirow[t]{3}{*}{ Food } & Exp. plants & 138 & $(19.4 \%)$ & 158 & $(22.4 \%)$ & 181 & $(25.9 \%)$ & 209 & (30.4\%) & 226 & $(33.4 \%)$ & 213 & $(31.6 \%)$ & 225 & (33.4\%) & 214 & $(31.8 \%)$ & 76 & $(55.1 \%)$ \\
\hline & Exp. Sales & 2.36 & $(3.1 \%)$ & 2.57 & $(3.3 \%)$ & 4.26 & $(5.5 \%)$ & 4.91 & $(6.1 \%)$ & 5.49 & $(6.3 \%)$ & 6.70 & $(7.2 \%)$ & 6.86 & $(6.8 \%)$ & 6.40 & $(6.1 \%)$ & 4.05 & (171.9\%) \\
\hline & Dom. sales & 72.61 & $(96.9 \%)$ & 76.32 & $(96.7 \%)$ & 72.91 & $(94.5 \%)$ & 76.15 & $(93.9 \%)$ & 81.04 & $(93.7 \%)$ & 86.83 & $(92.8 \%)$ & 93.36 & $(93.2 \%)$ & 98.74 & $(93.9 \%)$ & 26.14 & $(36.0 \%)$ \\
\hline \multirow[t]{3}{*}{ Textiles } & Exp. plants & 175 & $(26.5 \%)$ & 164 & $(25.4 \%)$ & 256 & $(41.3 \%)$ & 288 & $(48.7 \%)$ & 302 & $(54.2 \%)$ & 276 & $(49.8 \%)$ & 283 & $(51.4 \%)$ & 274 & $(49.7 \%)$ & 99 & $(56.6 \%)$ \\
\hline & Exp. Sales & 1.12 & $(8.1 \%)$ & 1.08 & $(7.7 \%)$ & 2.26 & $(17.0 \%)$ & 2.91 & $(18.3 \%)$ & 3.38 & (19.8\%) & 3.28 & (19.1\%) & 3.18 & (18.3\%) & 3.15 & $(17.8 \%)$ & 2.03 & (181.2\%) \\
\hline & Dom. sales & 12.74 & $(91.9 \%)$ & 13.00 & $(92.3 \%)$ & 11.01 & $(83.0 \%)$ & 12.99 & $(81.7 \%)$ & 13.70 & $(80.2 \%)$ & 13.93 & $(80.9 \%)$ & 14.13 & $(81.7 \%)$ & 14.53 & $(82.2 \%)$ & 1.78 & $(14.0 \%)$ \\
\hline \multirow[t]{3}{*}{ Wood } & Exp. plants & 21 & $(14.7 \%)$ & 19 & $(13.5 \%)$ & 39 & $(28.9 \%)$ & 50 & $(39.4 \%)$ & 52 & $(42.3 \%)$ & 46 & $(37.4 \%)$ & 44 & $(36.1 \%)$ & 47 & $(38.5 \%)$ & 26 & $(123.8 \%)$ \\
\hline & Exp. Sales & 0.12 & $(6.4 \%)$ & 0.20 & $(9.6 \%)$ & 0.38 & $(20.8 \%)$ & 0.52 & $(24.1 \%)$ & 0.59 & $(24.5 \%)$ & 0.61 & $(24.0 \%)$ & 0.58 & $(22.3 \%)$ & 0.49 & $(18.8 \%)$ & 0.37 & (294.1\%) \\
\hline & Dom. sales & 1.81 & $(93.6 \%)$ & 1.85 & $(90.4 \%)$ & 1.45 & $(79.2 \%)$ & 1.64 & $(75.9 \%)$ & 1.82 & $(75.5 \%)$ & 1.92 & $(76.0 \%)$ & 2.02 & $(77.7 \%)$ & 2.12 & $(81.2 \%)$ & 0.31 & $(17.2 \%)$ \\
\hline \multirow[t]{3}{*}{ Paper } & Exp. plants & 63 & $(19.9 \%)$ & 59 & $(18.8 \%)$ & 70 & $(22.6 \%)$ & 78 & $(25.4 \%)$ & 78 & $(25.5 \%)$ & 70 & $(23.0 \%)$ & 81 & $(26.6 \%)$ & 83 & $(27.2 \%)$ & 20 & (31.7\%) \\
\hline & Exp. Sales & 0.21 & $(1.5 \%)$ & 0.27 & $(1.8 \%)$ & 0.66 & $(4.6 \%)$ & 0.45 & $(3.0 \%)$ & 0.47 & $(2.8 \%)$ & 0.61 & (3.4\%) & 0.50 & $(2.7 \%)$ & 0.45 & $(2.4 \%)$ & 0.24 & (113.0\%) \\
\hline & Dom. sales & 13.72 & $(98.5 \%)$ & 14.50 & $(98.2 \%)$ & 13.46 & $(95.4 \%)$ & 14.49 & $(97.0 \%)$ & 16.38 & $(97.2 \%)$ & 17.08 & $(96.6 \%)$ & 17.87 & $(97.3 \%)$ & 18.33 & $(97.6 \%)$ & 4.61 & $(33.6 \%)$ \\
\hline \multirow[t]{3}{*}{ Chemical } & Exp. plants & 320 & $(37.8 \%)$ & 326 & $(38.9 \%)$ & 374 & $(45.5 \%)$ & 408 & $(50.5 \%)$ & 432 & $(54.1 \%)$ & 424 & $(52.9 \%)$ & 429 & $(53.6 \%)$ & 444 & $(55.5 \%)$ & 124 & $(38.8 \%)$ \\
\hline & Exp. Sales & 6.17 & $(13.0 \%)$ & 7.68 & $(14.8 \%)$ & 10.66 & $(20.9 \%)$ & 10.53 & (18.9\%) & 10.89 & $(17.4 \%)$ & 11.17 & (16.9\%) & 12.00 & $(17.9 \%)$ & 12.46 & $(17.6 \%)$ & 6.29 & (101.9\%) \\
\hline & Dom. sales & 41.43 & $(87.0 \%)$ & 44.11 & $(85.2 \%)$ & 40.24 & $(79.1 \%)$ & 45.14 & $(81.1 \%)$ & 51.65 & $(82.6 \%)$ & 55.07 & $(83.1 \%)$ & 54.97 & $(82.1 \%)$ & 58.37 & $(82.4 \%)$ & 16.94 & $(40.9 \%)$ \\
\hline \multirow[t]{3}{*}{ Glass } & Exp. plants & 68 & $(23.7 \%)$ & 75 & $(27.3 \%)$ & 86 & $(32.6 \%)$ & 89 & (35.0\%) & 94 & $(38.4 \%)$ & 88 & $(36.2 \%)$ & 97 & $(40.1 \%)$ & 91 & $(37.6 \%)$ & 23 & (33.8\%) \\
\hline & Exp. Sales & 1.11 & $(6.7 \%)$ & 1.59 & $(8.7 \%)$ & 2.45 & $(15.2 \%)$ & 2.64 & $(14.9 \%)$ & 2.80 & $(14.7 \%)$ & 2.72 & $(13.5 \%)$ & 2.66 & $(12.6 \%)$ & 2.76 & $(12.5 \%)$ & 1.66 & (149.3\%) \\
\hline & Dom. sales & 15.47 & $(93.3 \%)$ & 16.62 & $(91.3 \%)$ & 13.62 & $(84.8 \%)$ & 15.12 & $(85.1 \%)$ & 16.28 & $(85.3 \%)$ & 17.47 & $(86.5 \%)$ & 18.40 & $(87.4 \%)$ & 19.44 & $(87.5 \%)$ & 3.97 & $(25.7 \%)$ \\
\hline \multirow[t]{3}{*}{ Metals } & Exp. plants & 40 & $(36.7 \%)$ & 48 & $(45.3 \%)$ & 63 & $(61.8 \%)$ & 64 & $(62.1 \%)$ & 62 & $(62.0 \%)$ & 61 & $(61.0 \%)$ & 65 & $(65.0 \%)$ & 65 & $(65.0 \%)$ & 25 & $(62.5 \%)$ \\
\hline & Exp. Sales & 4.11 & $(17.8 \%)$ & 4.39 & $(17.4 \%)$ & 9.75 & $(33.0 \%)$ & 8.07 & $(24.3 \%)$ & 8.40 & $(22.5 \%)$ & 8.29 & $(22.8 \%)$ & 7.85 & $(21.5 \%)$ & 8.05 & $(21.6 \%)$ & 3.94 & (96.0\%) \\
\hline & Dom. sales & 18.93 & $(82.2 \%)$ & 20.88 & $(82.6 \%)$ & 19.78 & $(67.0 \%)$ & 25.09 & $(75.7 \%)$ & 28.87 & $(77.5 \%)$ & 28.08 & $(77.2 \%)$ & 28.63 & $(78.5 \%)$ & 29.18 & $(78.4 \%)$ & 10.26 & $(54.2 \%)$ \\
\hline \multirow[t]{3}{*}{ Machinery } & Exp. plants & 398 & $(40.4 \%)$ & 410 & $(41.9 \%)$ & 488 & $(51.2 \%)$ & 522 & $(56.7 \%)$ & 553 & $(61.5 \%)$ & 555 & $(62.0 \%)$ & 561 & $(63.0 \%)$ & 558 & $(62.7 \%)$ & 160 & $(40.2 \%)$ \\
\hline & Exp. Sales & 27.99 & $(32.9 \%)$ & 33.86 & $(37.5 \%)$ & 44.92 & $(58.2 \%)$ & 57.75 & (58.9\%) & 63.21 & $(54.7 \%)$ & 68.39 & $(54.7 \%)$ & 74.96 & (55.9\%) & 92.37 & $(57.7 \%)$ & 64.38 & (230.0\%) \\
\hline & Dom. sales & 57.03 & $(67.1 \%)$ & 56.44 & $(62.5 \%)$ & 32.27 & $(41.8 \%)$ & 40.35 & $(41.1 \%)$ & 52.35 & $(45.3 \%)$ & 56.69 & $(45.3 \%)$ & 59.24 & $(44.1 \%)$ & 67.66 & $(42.3 \%)$ & 10.63 & $(18.6 \%)$ \\
\hline \multirow[t]{3}{*}{ Total } & Exp. plants & 1223 & $(30.1 \%)$ & 1259 & (31.4\%) & 1557 & $(39.9 \%)$ & 1708 & $(45.0 \%)$ & 1799 & $(48.5 \%)$ & 1733 & $(46.9 \%)$ & 1785 & $(48.5 \%)$ & 1776 & $(48.2 \%)$ & 553 & $(45.2 \%)$ \\
\hline & Exp. Sales & 43 & $(15.6 \%)$ & 52 & $(17.5 \%)$ & 75 & $(26.9 \%)$ & 88 & $(27.5 \%)$ & 95 & $(26.7 \%)$ & 102 & $(26.9 \%)$ & 109 & $(27.3 \%)$ & 126 & $(29.0 \%)$ & 82.95 & (192.0\%) \\
\hline & Dom. sales & 234 & $(84.4 \%)$ & 244 & $(82.5 \%)$ & 205 & $(73.1 \%)$ & 231 & $(72.5 \%)$ & 262 & $(73.3 \%)$ & 277 & $(73.1 \%)$ & 289 & $(72.7 \%)$ & 308 & $(71.0 \%)$ & 74.64 & $(31.9 \%)$ \\
\hline
\end{tabular}

Note: Sales are measured in billion 1993 pesos 
Table 2. Heterogenity of plant responses to trade liberalization

\begin{tabular}{|c|c|c|c|c|c|c|c|c|}
\hline Sector & & 1993-1994 & 1994-1995 & $1995-1996$ & 1996-1997 & 1997-1998 & 1998-1999 & $1999-2000$ \\
\hline \multirow[t]{5}{*}{ Food } & Exit (\% all plants) & 1.4 & 1.3 & 1.4 & 2.0 & 0.6 & 0.0 & 0.0 \\
\hline & Start Export (\% domestic) & 6.7 & 6.5 & 7.1 & 7.2 & 3.6 & 6.7 & 3.6 \\
\hline & Stop Export (\% exporting) & 13.3 & 7.1 & 3.4 & 6.4 & 12.1 & 8.9 & 12.0 \\
\hline & Increase exports $>25 \%$ & 40.2 & 64.1 & 42.8 & 33.5 & 35.0 & 26.3 & 22.7 \\
\hline & Decrease exports $>25 \%$ & 21.4 & 14.5 & 27.7 & 25.7 & 27.9 & 31.4 & 37.9 \\
\hline \multirow{5}{*}{ Textile } & Exit (\% all plants) & 2.6 & 4.2 & 4.8 & 6.1 & 0.5 & 0.5 & 0.0 \\
\hline & Start Export (\% domestic) & 6.6 & 23.0 & 17.5 & 20.1 & 7.9 & 10.9 & 10.8 \\
\hline & Stop Export (\% exporting) & 24.4 & 8.0 & 10.3 & 13.5 & 15.0 & 8.3 & 13.4 \\
\hline & Increase exports >25\% & 32.3 & 68.5 & 56.4 & 41.4 & 35.5 & 24.9 & 25.7 \\
\hline & Decrease exports $>25 \%$ & 33.8 & 14.8 & 17.6 & 20.5 & 29.7 & 35.2 & 33.5 \\
\hline \multirow[t]{5}{*}{ Wood } & Exit (\% all plants) & 2.8 & 4.3 & 6.7 & 3.1 & 0.0 & 0.8 & 0.0 \\
\hline & Start Export (\% domestic) & 1.7 & 18.8 & 18.4 & 6.8 & 1.4 & 5.3 & 11.5 \\
\hline & Stop Export (\% exporting) & 19.0 & 5.6 & 12.8 & 6.0 & 13.5 & 13.0 & 13.6 \\
\hline & Increase exports >25\% & 64.7 & 82.4 & 64.7 & 48.9 & 24.4 & 30.0 & 18.4 \\
\hline & Decrease exports $>25 \%$ & 17.6 & 11.8 & 14.7 & 23.4 & 40.0 & 30.0 & 39.5 \\
\hline \multirow[t]{5}{*}{ Paper } & Exit (\% all plants) & 0.9 & 1.3 & 1.0 & 0.7 & 0.3 & 0.3 & 0.0 \\
\hline & Start Export (\% domestic) & 6.4 & 8.8 & 8.9 & 7.0 & 3.5 & 10.7 & 8.5 \\
\hline & Stop Export (\% exporting) & 31.7 & 18.6 & 18.6 & 21.8 & 20.5 & 20.0 & 21.0 \\
\hline & Increase exports $>25 \%$ & 58.1 & 62.5 & 40.4 & 37.7 & 38.7 & 23.2 & 34.4 \\
\hline & Decrease exports $>25 \%$ & 14.0 & 20.8 & 26.3 & 31.1 & 27.4 & 42.9 & 29.7 \\
\hline \multirow[t]{5}{*}{ Chemical } & Exit (\% all plants) & 1.1 & 2.3 & 1.8 & 1.6 & 0.6 & 0.4 & 0.0 \\
\hline & Start Export (\% domestic) & 11.3 & 15.9 & 14.8 & 14.9 & 10.7 & 13.6 & 13.7 \\
\hline & Stop Export (\% exporting) & 15.9 & 8.7 & 8.0 & 8.1 & 11.1 & 10.6 & 8.4 \\
\hline & Increase exports $>25 \%$ & 48.1 & 59.2 & 37.2 & 38.6 & 36.8 & 30.2 & 28.8 \\
\hline & Decrease exports $>25 \%$ & 21.2 & 15.6 & 22.4 & 23.3 & 22.5 & 30.2 & 26.0 \\
\hline \multirow[t]{5}{*}{ Glass } & Exit (\% all plants) & 4.2 & 4.0 & 4.2 & 3.9 & 1.2 & 0.8 & 0.0 \\
\hline & Start Export (\% domestic) & 7.6 & 7.9 & 5.9 & 6.4 & 2.7 & 7.2 & 2.1 \\
\hline & Stop Export (\% exporting) & 10.8 & 5.4 & 6.0 & 3.4 & 10.8 & 3.4 & 9.3 \\
\hline & Increase exports $>25 \%$ & 44.8 & 71.4 & 35.4 & 27.4 & 25.3 & 18.8 & 21.6 \\
\hline & Decrease exports $>25 \%$ & 13.8 & 8.6 & 17.7 & 25.0 & 19.3 & 32.9 & 27.3 \\
\hline \multirow[t]{5}{*}{ Metals } & Exit (\% all plants) & 2.8 & 3.8 & 0.0 & 3.9 & 0.0 & 0.0 & 0.0 \\
\hline & Start Export (\% domestic) & 15.2 & 34.5 & 17.9 & 16.7 & 7.9 & 20.5 & 5.7 \\
\hline & Stop Export (\% exporting) & 5.0 & 6.4 & 9.5 & 11.1 & 6.5 & 6.6 & 3.1 \\
\hline & Increase exports $>25 \%$ & 57.9 & 75.0 & 40.4 & 37.5 & 29.3 & 19.3 & 27.0 \\
\hline & Decrease exports $>25 \%$ & 13.2 & 6.8 & 40.4 & 16.1 & 39.7 & 42.1 & 31.7 \\
\hline \multirow[t]{5}{*}{ Machinery } & Exit (\% all plants) & 0.9 & 2.7 & 4.4 & 2.7 & 1.2 & 0.7 & 0.0 \\
\hline & Start Export (\% domestic) & 11.5 & 19.2 & 15.0 & 16.6 & 10.1 & 12.8 & 14.6 \\
\hline & Stop Export (\% exporting) & 13.7 & 6.3 & 5.9 & 5.8 & 6.4 & 6.5 & 9.1 \\
\hline & Increase exports $>25 \%$ & 50.0 & 64.7 & 59.1 & 56.5 & 13.0 & 22.7 & 26.1 \\
\hline & Decrease exports $>25 \%$ & 37.5 & 11.8 & 13.6 & 13.0 & 30.4 & 27.3 & 21.7 \\
\hline
\end{tabular}


Table 3. Estimates of production functions. Fixed effects estimation and semiparametric estimation

\begin{tabular}{|c|c|c|c|c|c|c|c|c|c|c|c|c|}
\hline \multirow[b]{2}{*}{ sector } & \multicolumn{6}{|c|}{ Fixed effects } & \multicolumn{6}{|c|}{ Semiparametric estimation } \\
\hline & \multicolumn{2}{|c|}{ capital } & \multicolumn{2}{|c|}{ unskilled labor } & \multicolumn{2}{|c|}{ skilled labor } & \multicolumn{2}{|c|}{ capital } & \multicolumn{2}{|c|}{ unskilled labor } & \multicolumn{2}{|c|}{ skilled labor } \\
\hline & Coeff. & S.E. & Coeff. & S.E & Coeff. & S.E & Coeff. & S.E. & Coeff. & S.E & Coeff. & S.E \\
\hline & $(1)$ & $(2)$ & $(3)$ & $(4)$ & $(5)$ & $(6)$ & $(7)$ & $(8)$ & $(9)$ & $(10)$ & $(11)$ & $(12)$ \\
\hline Food processing & $0.231^{\star \star}$ & 0.020 & $0.426^{\star \star}$ & 0.027 & $0.241^{\star \star}$ & 0.022 & $0.340 * *$ & 0.048 & $0.294^{\star *}$ & 0.033 & $0.303^{\star \star}$ & 0.031 \\
\hline Textiles & $0.123^{\star *}$ & 0.020 & $0.603^{* *}$ & 0.028 & $0.184^{* *}$ & 0.025 & $0.352^{\star *}$ & 0.043 & $0.487^{* *}$ & 0.030 & $0.307^{* *}$ & 0.029 \\
\hline Wood & $0.241^{* *}$ & 0.050 & $0.617^{* *}$ & 0.060 & 0.058 & 0.060 & $0.380 * *$ & 0.106 & $0.345^{\star \star}$ & 0.086 & $0.345^{\star *}$ & 0.063 \\
\hline Paper & $0.127^{* *}$ & 0.026 & $0.485^{\star *}$ & 0.040 & $0.277^{* *}$ & 0.038 & 0.196 ** & 0.085 & $0.375^{\star *}$ & 0.047 & 0.391 ** & 0.030 \\
\hline Chemical & $0.206^{\star \star}$ & 0.017 & $0.507^{* *}$ & 0.023 & $0.229 * \star$ & 0.021 & $0.522^{* *}$ & 0.036 & $0.137^{* *}$ & 0.036 & 0.500 ** & 0.031 \\
\hline Glass & $0.145^{\star \star}$ & 0.031 & $0.671^{\star *}$ & 0.051 & 0.016 & 0.046 & $0.351^{* *}$ & 0.109 & $0.148^{* *}$ & 0.053 & $0.388 * *$ & 0.049 \\
\hline Basic metals & $0.116^{\star \star}$ & 0.058 & 0.586 ** & 0.058 & -0.011 & 0.059 & $0.485^{\star *}$ & 0.149 & 0.516 ** & 0.100 & $0.221^{* \star}$ & 0.075 \\
\hline Machinery & $0.253^{\star *}$ & 0.015 & $0.685^{\star \star}$ & 0.018 & $0.154^{\star *}$ & 0.017 & $0.475^{\star *}$ & 0.026 & $0.289 * *$ & 0.025 & $0.402^{\star \star}$ & 0.022 \\
\hline
\end{tabular}

Note: **Significant at 95 percent level. *Significant at 90 percent level. Bootstrap standard errors are presented for semiparametric estimation 
Table 4. Aggregate industry-level productivity and its components

\begin{tabular}{|c|c|c|c|c|c|c|c|c|c|}
\hline Sector & 1993 & 1994 & 1995 & 1996 & 1997 & 1998 & 1999 & 2000 & $\begin{array}{c}1993-2000 \\
\text { Change }\end{array}$ \\
\hline \multicolumn{10}{|c|}{ A. Aggregate productivity } \\
\hline Food & 0.748 & 0.801 & 0.761 & 0.770 & 0.800 & 0.884 & 0.937 & 0.978 & 0.230 \\
\hline Textiles & -0.020 & 0.085 & 0.133 & 0.274 & 0.278 & 0.292 & 0.277 & 0.260 & 0.280 \\
\hline Wood & 0.188 & 0.191 & 0.072 & 0.261 & 0.285 & 0.312 & 0.347 & 0.336 & 0.148 \\
\hline Paper & 0.464 & 0.527 & 0.576 & 0.575 & 0.628 & 0.650 & 0.682 & 0.703 & 0.239 \\
\hline Chemical & 0.199 & 0.274 & 0.258 & 0.272 & 0.333 & 0.381 & 0.354 & 0.357 & 0.159 \\
\hline Glass & 0.746 & 0.870 & 0.743 & 0.956 & 1.043 & 1.080 & 1.133 & 1.182 & 0.436 \\
\hline Metals & 0.141 & 0.227 & 0.405 & 0.513 & 0.571 & 0.555 & 0.598 & 0.608 & 0.467 \\
\hline Machinery & 0.301 & 0.354 & 0.357 & 0.568 & 0.665 & 0.640 & 0.646 & 0.801 & 0.499 \\
\hline \multicolumn{10}{|c|}{ B. Unweighted productivity } \\
\hline Food & 0 & 0.043 & 0.076 & 0.063 & 0.055 & 0.117 & 0.140 & 0.100 & 0.100 \\
\hline Textiles & 0 & 0.039 & -0.050 & 0.040 & 0.064 & 0.010 & -0.013 & -0.054 & -0.054 \\
\hline Wood & 0 & 0.003 & -0.161 & -0.001 & -0.021 & 0.031 & 0.016 & -0.064 & -0.064 \\
\hline Paper & 0 & 0.053 & -0.024 & -0.001 & 0.150 & 0.168 & 0.165 & 0.181 & 0.181 \\
\hline Chemical & 0 & 0.027 & -0.017 & 0.054 & 0.034 & 0.063 & 0.034 & -0.008 & -0.008 \\
\hline Glass & 0 & 0.075 & -0.201 & -0.130 & 0.015 & 0.073 & 0.214 & 0.147 & 0.147 \\
\hline Metals & 0 & 0.073 & 0.127 & 0.224 & 0.326 & 0.417 & 0.391 & 0.333 & 0.333 \\
\hline Machinery & 0 & 0.054 & -0.115 & 0.029 & 0.091 & 0.107 & 0.062 & 0.081 & 0.081 \\
\hline \multicolumn{10}{|c|}{ C. Covariance Term } \\
\hline Food & 0.748 & 0.758 & 0.685 & 0.707 & 0.745 & 0.766 & 0.797 & 0.878 & 0.129 \\
\hline Textiles & -0.020 & 0.046 & 0.183 & 0.234 & 0.213 & 0.282 & 0.290 & 0.314 & 0.334 \\
\hline Wood & 0.188 & 0.188 & 0.232 & 0.262 & 0.306 & 0.281 & 0.331 & 0.400 & 0.211 \\
\hline Paper & 0.464 & 0.475 & 0.600 & 0.576 & 0.478 & 0.481 & 0.517 & 0.523 & 0.058 \\
\hline Chemical & 0.199 & 0.247 & 0.275 & 0.218 & 0.299 & 0.318 & 0.320 & 0.366 & 0.167 \\
\hline Glass & 0.746 & 0.795 & 0.939 & 1.085 & 1.027 & 1.007 & 0.919 & 1.036 & 0.289 \\
\hline Metals & 0.141 & 0.154 & 0.278 & 0.289 & 0.245 & 0.139 & 0.207 & 0.275 & 0.134 \\
\hline Machinery & 0.301 & 0.301 & 0.472 & 0.538 & 0.574 & 0.533 & 0.584 & 0.720 & 0.418 \\
\hline
\end{tabular}


Table 5. Productivity anlysis of plants that exit the market

\section{A. Average productivity before exit relative to plants that do not exit the market}

\begin{tabular}{|c|c|c|c|c|c|c|c|}
\hline \multirow[b]{2}{*}{ Sector } & & \multicolumn{6}{|c|}{ Years before exit } \\
\hline & & Exit - 5 & Exit - 4 & Exit - 3 & Exit - 2 & Exit - 1 & Exit \\
\hline \multirow[t]{3}{*}{ Food } & No. of plants & 0 & 4 & 18 & 28 & 37 & 47 \\
\hline & Average TFP & - & -0.126 & -0.363 & -0.704 & -0.533 & -1.034 \\
\hline & Average Output & - & $86.3 \%$ & $44.4 \%$ & $37.7 \%$ & $37.2 \%$ & $23.9 \%$ \\
\hline \multirow[t]{3}{*}{ Textiles } & No. of plants & 3 & 6 & 42 & 72 & 99 & 116 \\
\hline & Average TFP & -0.023 & 0.132 & -0.135 & -0.088 & -0.260 & -0.723 \\
\hline & Average Output & $69.2 \%$ & $60.4 \%$ & $49.7 \%$ & $44.6 \%$ & $43.1 \%$ & $29.1 \%$ \\
\hline \multirow[t]{3}{*}{ Wood } & No. of plants & 1 & 1 & 5 & 14 & 20 & 24 \\
\hline & Average TFP & 0.050 & -0.541 & 0.327 & -0.060 & -0.107 & -0.746 \\
\hline & Average Output & $27.8 \%$ & $19.0 \%$ & $81.7 \%$ & $56.6 \%$ & $37.7 \%$ & $30.6 \%$ \\
\hline \multirow[t]{3}{*}{ Paper } & No. of plants & 1 & 2 & 4 & 7 & 11 & 14 \\
\hline & Average TFP & 0.976 & 0.579 & -0.685 & -0.411 & -0.432 & -0.767 \\
\hline & Average Output & $65.9 \%$ & $36.8 \%$ & $47.5 \%$ & $37.0 \%$ & $42.4 \%$ & $20.0 \%$ \\
\hline \multirow{3}{*}{ Chemical } & No. of plants & 3 & 8 & 21 & 36 & 55 & 64 \\
\hline & Average TFP & 0.127 & -0.175 & -0.217 & -0.027 & -0.191 & -0.671 \\
\hline & Average Output & $72.9 \%$ & $52.3 \%$ & $45.4 \%$ & $35.3 \%$ & $37.4 \%$ & $26.4 \%$ \\
\hline \multirow[t]{3}{*}{ Glass } & No. of plants & 2 & 5 & 15 & 26 & 37 & 49 \\
\hline & Average TFP & 0.047 & -0.120 & -0.532 & -0.748 & -0.659 & -1.038 \\
\hline & Average Output & $15.2 \%$ & $39.9 \%$ & $24.2 \%$ & $20.3 \%$ & $20.4 \%$ & $15.0 \%$ \\
\hline \multirow[t]{3}{*}{ Metals } & No. of plants & 0 & 0 & 4 & 4 & 8 & 11 \\
\hline & Average TFP & - & - & -0.151 & -0.957 & -0.167 & -0.838 \\
\hline & Average Output & - & - & $39.6 \%$ & $29.6 \%$ & $35.1 \%$ & $21.2 \%$ \\
\hline \multirow[t]{3}{*}{ Machinery } & No. of plants & 6 & 17 & 42 & 84 & 110 & 119 \\
\hline & Average TFP & -0.486 & -0.154 & -0.016 & -0.067 & -0.150 & -0.779 \\
\hline & Average Output & $38.4 \%$ & $31.5 \%$ & $30.6 \%$ & $31.3 \%$ & $29.8 \%$ & $23.0 \%$ \\
\hline
\end{tabular}

Note: Entries for Average TFP represent the difference between the average productivity of plants that exit and the average productivity of the relevant surviving plants

Entries for Average Output represent the average output of plants that exit as a percenatge of the average output of the relevant surviving plants

\section{B. The contribution of plants that exit to the components af aggregate productivity}

\begin{tabular}{|c|c|c|c|c|c|c|c|c|c|}
\hline Sector & Component & 1993 & 1994 & 1995 & 1996 & 1997 & 1998 & 1999 & 2000 \\
\hline \multirow[t]{2}{*}{ Food } & Unweighted & -0.040 & -0.029 & -0.034 & -0.015 & -0.004 & 0.000 & 0 & 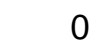 \\
\hline & Covariance & 0.043 & 0.041 & 0.034 & 0.019 & 0.005 & 0.000 & 0 & 0 \\
\hline \multirow[t]{2}{*}{ Textiles } & Unweighted & -0.036 & -0.040 & -0.044 & -0.036 & -0.001 & -0.003 & 0 & $\overline{0}$ \\
\hline & Covariance & 0.024 & 0.043 & 0.035 & 0.038 & 0.003 & 0.003 & 0 & 0 \\
\hline \multirow[t]{2}{*}{ Wood } & Unweighted & -0.016 & -0.022 & -0.096 & 0.001 & 0.000 & -0.012 & 0 & $\overline{0}$ \\
\hline & Covariance & 0.028 & 0.041 & 0.080 & 0.000 & 0.000 & 0.012 & 0 & 0 \\
\hline \multirow[t]{2}{*}{ Paper } & Unweighted & -0.012 & -0.021 & -0.016 & -0.009 & 0.001 & 0.001 & 0 & $\overline{0}$ \\
\hline & Covariance & 0.010 & 0.018 & 0.012 & 0.008 & 0.000 & -0.001 & 0 & 0 \\
\hline \multirow[t]{2}{*}{ Chemical } & Unweighted & -0.004 & -0.024 & -0.029 & -0.005 & -0.002 & -0.002 & 0 & $\overline{0}$ \\
\hline & Covariance & 0.014 & 0.029 & 0.027 & 0.007 & 0.001 & 0.002 & 0 & 0 \\
\hline \multirow[t]{2}{*}{ Glass } & Unweighted & -0.074 & -0.048 & -0.104 & -0.090 & -0.040 & -0.009 & 0 & $\overline{0}$ \\
\hline & Covariance & 0.078 & 0.060 & 0.082 & 0.082 & 0.039 & 0.009 & 0 & 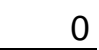 \\
\hline \multirow[t]{2}{*}{ Metals } & Unweighted & -0.008 & -0.036 & -0.027 & -0.045 & 0.000 & 0.000 & 0 & $\overline{0}$ \\
\hline & Covariance & 0.010 & 0.037 & 0.030 & 0.046 & 0.000 & 0.000 & 0 & 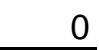 \\
\hline \multirow[t]{2}{*}{ Machinery } & Unweighted & -0.002 & -0.019 & -0.052 & -0.024 & -0.019 & -0.002 & 0 & 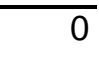 \\
\hline & Covariance & -0.002 & 0.021 & 0.040 & 0.025 & 0.020 & 0.002 & 0 & 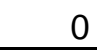 \\
\hline
\end{tabular}


Table 6. Explained variance and eigenvectors for the first three principal components

\begin{tabular}{|c|c|c|c|c|c|c|c|c|}
\hline & Food & Textiles & Wood & Paper & Chemical & Glass & Metals & Machinery \\
\hline \multicolumn{9}{|c|}{ First Principal Component } \\
\hline Expl. Variance & $65.4 \%$ & $48.7 \%$ & $49.5 \%$ & $58.6 \%$ & $50.3 \%$ & $67.6 \%$ & $50.8 \%$ & $48.3 \%$ \\
\hline Prod 93 & 0.652 & 0.013 & 0.213 & 0.457 & 0.304 & 0.635 & 0.320 & 0.289 \\
\hline Prod 94 & 0.674 & 0.036 & 0.239 & 0.511 & 0.367 & 0.694 & 0.305 & 0.324 \\
\hline Prod 95 & 0.673 & 0.154 & 0.311 & 0.573 & 0.399 & 0.680 & 0.440 & 0.333 \\
\hline Prod 96 & 0.692 & 0.186 & 0.352 & 0.635 & 0.409 & 0.681 & 0.455 & 0.395 \\
\hline Prod 97 & 0.721 & 0.213 & 0.446 & 0.641 & 0.435 & 0.759 & 0.449 & 0.425 \\
\hline Prod 98 & 0.732 & 0.237 & 0.462 & 0.631 & 0.453 & 0.763 & 0.403 & 0.429 \\
\hline Prod 99 & 0.750 & 0.226 & 0.497 & 0.615 & 0.425 & 0.742 & 0.419 & 0.429 \\
\hline Prod 00 & 0.723 & 0.216 & 0.457 & 0.614 & 0.442 & 0.702 & 0.452 & 0.434 \\
\hline Output 93 & 0.903 & 0.937 & 0.879 & 0.872 & 0.899 & 0.905 & 0.914 & 0.859 \\
\hline Output 94 & 0.909 & 0.950 & 0.905 & 0.891 & 0.910 & 0.927 & 0.919 & 0.881 \\
\hline Output 95 & 0.907 & 0.978 & 0.894 & 0.901 & 0.914 & 0.913 & 0.918 & 0.879 \\
\hline Output 96 & 0.907 & 0.979 & 0.929 & 0.921 & 0.925 & 0.917 & 0.918 & 0.933 \\
\hline Output 97 & 0.920 & 0.984 & 0.931 & 0.929 & 0.934 & 0.931 & 0.923 & 0.931 \\
\hline Output 98 & 0.909 & 0.983 & 0.929 & 0.926 & 0.918 & 0.929 & 0.931 & 0.921 \\
\hline Output 99 & 0.901 & 0.980 & 0.937 & 0.923 & 0.921 & 0.933 & 0.927 & 0.905 \\
\hline Output 00 & 0.860 & 0.972 & 0.931 & 0.913 & 0.917 & 0.921 & 0.923 & 0.918 \\
\hline \multicolumn{9}{|c|}{ Second Principal Component } \\
\hline Expl. Variance & $18.7 \%$ & $26.3 \%$ & $23.7 \%$ & $20.5 \%$ & $31.9 \%$ & $14.5 \%$ & $33.7 \%$ & $30.6 \%$ \\
\hline Prod 93 & -0.427 & -0.571 & -0.518 & -0.359 & -0.700 & -0.375 & -0.675 & -0.614 \\
\hline Prod 94 & -0.442 & -0.637 & -0.606 & -0.459 & -0.755 & -0.398 & -0.696 & -0.696 \\
\hline Prod 95 & -0.451 & -0.734 & -0.700 & -0.382 & -0.749 & -0.455 & -0.729 & -0.689 \\
\hline Prod 96 & -0.524 & -0.756 & -0.528 & -0.537 & -0.780 & -0.425 & -0.775 & -0.750 \\
\hline Prod 97 & -0.540 & -0.827 & -0.639 & -0.609 & -0.767 & -0.486 & -0.802 & -0.781 \\
\hline Prod 98 & -0.511 & -0.784 & -0.718 & -0.647 & -0.750 & -0.444 & -0.812 & -0.794 \\
\hline Prod 99 & -0.497 & -0.684 & -0.695 & -0.629 & -0.678 & -0.444 & -0.783 & -0.747 \\
\hline Prod 00 & -0.460 & -0.687 & -0.653 & -0.594 & -0.657 & -0.376 & -0.719 & -0.667 \\
\hline Output 93 & 0.374 & 0.175 & 0.231 & 0.377 & 0.305 & $\overline{0.3}$ & 0.326 & 0.322 \\
\hline Output 94 & 0.370 & 0.151 & 0.241 & 0.371 & 0.316 & 0.315 & 0.327 & 0.326 \\
\hline Output 95 & 0.376 & 0.137 & 0.310 & 0.382 & 0.333 & 0.347 & 0.355 & 0.297 \\
\hline Output 96 & 0.363 & 0.128 & 0.290 & 0.359 & 0.338 & 0.353 & 0.342 & 0.300 \\
\hline Output 97 & 0.364 & 0.099 & 0.270 & 0.335 & 0.329 & 0.335 & 0.340 & 0.291 \\
\hline Output 98 & 0.383 & 0.101 & 0.272 & 0.320 & 0.325 & 0.337 & 0.336 & 0.293 \\
\hline Output 99 & 0.376 & 0.101 & 0.259 & 0.315 & 0.318 & 0.310 & 0.307 & 0.308 \\
\hline Output 00 & 0.400 & 0.090 & 0.221 & 0.302 & 0.307 & 0.302 & 0.316 & 0.313 \\
\hline \multicolumn{9}{|c|}{ Third Principal Component } \\
\hline Expl. Variance & $5.1 \%$ & $8.5 \%$ & $8.1 \%$ & $7.0 \%$ & $6.5 \%$ & $5.0 \%$ & $5.5 \%$ & $6.4 \%$ \\
\hline Prod 93 & -0.475 & -0.642 & -0.677 & -0.673 & -0.438 & -0.490 & -0.482 & -0.568 \\
\hline Prod 94 & -0.446 & -0.576 & -0.564 & -0.570 & -0.403 & -0.439 & -0.478 & -0.499 \\
\hline Prod 95 & -0.253 & -0.282 & -0.306 & -0.257 & -0.317 & -0.129 & -0.279 & -0.263 \\
\hline Prod 96 & -0.049 & -0.088 & 0.018 & 0.084 & -0.187 & -0.047 & -0.028 & 0.008 \\
\hline Prod 97 & 0.171 & 0.144 & 0.332 & 0.182 & 0.142 & 0.076 & 0.148 & 0.152 \\
\hline Prod 98 & 0.279 & 0.310 & 0.318 & 0.233 & 0.327 & 0.182 & 0.294 & 0.256 \\
\hline Prod 99 & 0.309 & 0.496 & 0.315 & 0.282 & 0.457 & 0.329 & 0.320 & 0.364 \\
\hline Prod 00 & 0.342 & 0.395 & 0.274 & 0.238 & 0.439 & 0.444 & 0.359 & 0.369 \\
\hline Output 93 & -0.050 & -0.062 & -0.135 & -0.090 & -0.066 & -0.056 & -0.036 & -0.080 \\
\hline Output 94 & -0.058 & -0.080 & -0.125 & -0.076 & -0.062 & -0.039 & -0.040 & -0.078 \\
\hline Output 95 & -0.041 & -0.051 & -0.055 & -0.037 & -0.052 & -0.022 & -0.002 & -0.068 \\
\hline Output 96 & 0.009 & -0.032 & -0.032 & 0.008 & -0.020 & 0.000 & -0.004 & 0.002 \\
\hline Output 97 & 0.022 & -0.012 & 0.029 & 0.045 & -0.005 & 0.015 & 0.008 & 0.021 \\
\hline Output 98 & 0.038 & 0.008 & 0.025 & 0.071 & 0.021 & 0.020 & 0.009 & 0.035 \\
\hline Output 99 & 0.037 & -0.003 & 0.036 & 0.091 & 0.028 & 0.030 & 0.003 & 0.034 \\
\hline Output 00 & 0.054 & 0.010 & 0.019 & 0.099 & 0.028 & 0.033 & 0.011 & 0.035 \\
\hline
\end{tabular}


Table 7. Productivity and output performance by deciles of the first principal component

\begin{tabular}{|c|c|c|c|c|c|c|c|c|c|c|c|c|c|}
\hline \multirow[t]{3}{*}{ Sector } & \multirow[t]{3}{*}{ Plants } & \multirow{2}{*}{\multicolumn{2}{|c|}{ Productivity Index }} & \multirow{2}{*}{\multicolumn{4}{|c|}{ Output }} & \multicolumn{6}{|c|}{ Contributions to aggregate productivity } \\
\hline & & & & & & & & \multicolumn{2}{|c|}{ Unweighted } & \multicolumn{2}{|c|}{ Covariance } & \multicolumn{2}{|c|}{ Total } \\
\hline & & $\begin{array}{c}\text { Average } \\
1993 \\
(1) \\
\end{array}$ & $\begin{array}{c}\text { Change } \\
93-00 \\
(2)\end{array}$ & $\begin{array}{c}\text { Average } \\
1993 \\
(3) \\
\end{array}$ & $\begin{array}{c}\% \text { Change } \\
93-00 \\
(4)\end{array}$ & $\begin{array}{c}\% \text { of total } \\
93-00 \\
(5)\end{array}$ & $\begin{array}{c}\% \text { of growth } \\
93-00 \\
(6)\end{array}$ & $\begin{array}{c}\text { Sum } \\
1993 \\
(7) \\
\end{array}$ & $\begin{array}{c}\text { Change } \\
93-00 \\
(8) \\
\end{array}$ & $\begin{array}{c}\text { Sum } \\
1993 \\
(9)\end{array}$ & $\begin{array}{c}\text { Change } \\
93-00 \\
(10)\end{array}$ & $\begin{array}{c}\text { Sum } \\
1993 \\
(11)\end{array}$ & $\begin{array}{c}\text { Change } \\
93-00 \\
(12)\end{array}$ \\
\hline \multirow[t]{3}{*}{ Food } & All & 0.043 & 0.059 & 109977 & 40.90 & & & 0.040 & 0.060 & 0.705 & 0.158 & 0.745 & 0.218 \\
\hline & 1st decile & -0.918 & -0.395 & 18288 & 7.74 & 1.46 & 0.31 & -0.085 & -0.044 & 0.071 & 0.051 & -0.014 & -0.002 \\
\hline & 10th decile & 1.161 & 0.274 & 527536 & 48.87 & 49.11 & 57.74 & 0.109 & 0.034 & 0.559 & 0.088 & 0.668 & 0.163 \\
\hline \multirow[t]{3}{*}{ Textiles } & All & 0.044 & -0.097 & 23468 & 35.63 & & & 0.036 & -0.089 & -0.044 & 0.345 & -0.008 & 0.257 \\
\hline & 1st decile & -0.324 & -0.981 & 5225 & -54.14 & 1.31 & -3.35 & -0.027 & -0.101 & 0.021 & 0.092 & -0.006 & -0.004 \\
\hline & 10th decile & 0.020 & 0.337 & 107638 & 48.47 & 49.08 & 62.97 & 0.002 & 0.034 & -0.038 & 0.209 & -0.036 & 0.222 \\
\hline \multirow[t]{3}{*}{ Wood } & All & 0.019 & -0.059 & 15180 & 44.64 & & & 0.016 & -0.055 & 0.160 & 0.218 & 0.176 & 0.162 \\
\hline & 1st decile & -0.253 & -1.402 & 3275 & -5.35 & 1.56 & -0.24 & -0.019 & -0.130 & 0.018 & 0.114 & -0.001 & -0.012 \\
\hline & 10th decile & 0.262 & 0.203 & 58695 & 63.86 & 41.46 & 55.78 & 0.022 & 0.024 & 0.115 & 0.093 & 0.137 & 0.096 \\
\hline \multirow[t]{3}{*}{ Paper } & All & 0.013 & 0.170 & 45371 & 36.69 & & & 0.012 & 0.168 & 0.454 & 0.066 & 0.467 & 0.236 \\
\hline & 1st decile & -0.564 & -0.513 & 5647 & -0.80 & 1.00 & -0.03 & -0.054 & -0.052 & 0.047 & 0.066 & -0.006 & -0.003 \\
\hline & 10th decile & 0.465 & 0.455 & 209860 & 35.56 & 48.29 & 46.02 & 0.046 & 0.048 & 0.328 & -0.024 & 0.374 & 0.090 \\
\hline \multirow[t]{3}{*}{ Chemical } & All & 0.004 & -0.021 & 58929 & 48.54 & & & 0.004 & -0.020 & 0.185 & 0.168 & 0.189 & 0.149 \\
\hline & 1st decile & -0.740 & -0.393 & 11139 & -21.64 & 1.31 & -0.84 & -0.068 & -0.042 & 0.054 & 0.046 & -0.013 & 0.004 \\
\hline & 10th decile & 0.558 & 0.123 & 325061 & 46.53 & 55.90 & 53.42 & 0.052 & 0.015 & 0.186 & 0.060 & 0.237 & 0.072 \\
\hline \multirow[t]{3}{*}{ Glass } & All & 0.089 & 0.039 & 67674 & 30.78 & & & 0.074 & 0.053 & 0.668 & 0.277 & 0.742 & 0.324 \\
\hline & 1st decile & -0.824 & -0.454 & 7673 & -38.66 & 0.70 & -1.38 & -0.066 & -0.055 & 0.059 & 0.071 & -0.007 & 0.002 \\
\hline & 10th decile & 0.944 & 0.561 & 370493 & 27.49 & 55.07 & 49.31 & 0.079 & 0.070 & 0.483 & 0.097 & 0.562 & 0.228 \\
\hline \multirow[t]{3}{*}{ Metals } & All & 0.009 & 0.319 & 229671 & 64.24 & & & 0.008 & 0.313 & 0.131 & 0.144 & 0.140 & 0.462 \\
\hline & 1st decile & -0.966 & -0.092 & 65426 & 8.48 & 2.03 & 0.35 & -0.080 & -0.015 & 0.052 & 0.052 & -0.027 & 0.012 \\
\hline & 10th decile & 0.374 & 0.599 & 1073924 & 85.02 & 52.92 & 63.15 & 0.034 & 0.063 & 0.056 & 0.125 & 0.091 & 0.333 \\
\hline \multirow[t]{3}{*}{ Machinery } & All & 0.003 & 0.077 & 96234 & 86.10 & & & 0.002 & 0.075 & 0.303 & 0.412 & 0.305 & 0.486 \\
\hline & 1st decile & -0.695 & -0.094 & 23256 & -9.17 & 1.49 & -0.26 & -0.061 & -0.016 & 0.049 & 0.027 & -0.011 & 0.004 \\
\hline & 10th decile & 0.579 & 0.302 & 663603 & 100.32 & 71.19 & 80.63 & 0.051 & 0.035 & 0.278 & 0.338 & 0.329 & 0.423 \\
\hline
\end{tabular}


Table 8. Output and productivity in 1993 and output and productivity growth between 1993 and 2000 by export status in 1993 and dynamic export status

\begin{tabular}{|c|c|c|c|c|c|c|c|c|c|}
\hline \multirow[t]{2}{*}{ 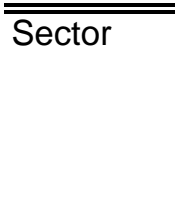 } & \multirow{2}{*}{$\begin{array}{l}\text { Dependent } \\
\text { Variable }\end{array}$} & \multicolumn{2}{|c|}{ Export Status 1993} & \multicolumn{6}{|c|}{ Dynamic Exporting Status } \\
\hline & & $\begin{array}{r}\text { Non-exp. } \\
\text { (Const.) } \\
(1)\end{array}$ & $\begin{array}{c}\text { Export } \\
\text { (Coeff.) } \\
(2)\end{array}$ & $\begin{array}{c}\text { Never } \\
\text { (Const.) } \\
(3)\end{array}$ & $\begin{array}{c}\text { Exit } \\
\text { (Coeff.) } \\
(4)\end{array}$ & $\begin{array}{c}\text { Begin } \\
\text { (Coeff.) } \\
(5)\end{array}$ & $\begin{array}{c}\text { Temp. } \\
\text { (Coeff.) } \\
(6)\end{array}$ & $\begin{array}{c}\text { Multiple } \\
\text { (Coeff.) } \\
(7)\end{array}$ & $\begin{array}{c}\text { Always } \\
\text { (Coeff.) } \\
(8) \\
\end{array}$ \\
\hline \multirow[t]{4}{*}{$\overline{\text { Food }}$} & Outp & 98300 & 60800 & 89000 & n.s. & 38800 & n.s. & n.s. & 89900 \\
\hline & Productivity 93 & n.s. & 0.182 & n.s. & n.s. & 0.227 & n.s. & n.s. & 0.234 \\
\hline & Output growth & 39600 & 28000 & 31600 & n.s. & n.s. & n.s. & n.s. & 39800 \\
\hline & Productivity growth & 0.085 & n.s. & 0.113 & n.s. & n.s. & n.s. & -0.438 & n.s. \\
\hline \multirow[t]{4}{*}{ Textiles } & Outp & 15300 & 28500 & 10400 & n.s. & 11300 & n.s. & 14400 & 42200 \\
\hline & tivity 93 & n.s. & n.s. & n.s. & n.s. & n.s. & n.s. & n.s. & n.s. \\
\hline & growth & 5478 & 10000 & n.s. & n.s. & 11600 & n.s. & n.s. & 22000 \\
\hline & Productivity growth & -0.109 & n.s. & -0.239 & -0.611 & 0.262 & n.s. & n.s. & 0.317 \\
\hline \multirow[t]{4}{*}{$\overline{\text { Wood }}$} & Outp & 12600 & 14400 & 10200 & n.s. & n.s. & n.s. & 11400 & 20100 \\
\hline & tivity 93 & n.s. & n.s. & n.s. & n.s. & n.s. & n.s. & 0.528 & \\
\hline & Output growth & 6017 & n.s. & 4140 & n.s. & n.s. & n.s. & n.s. & 10400 \\
\hline & Productivity growth & n.s. & n.s. & n.s. & n.s. & n.s. & n.s. & n.s. & n.s. \\
\hline \multirow[t]{4}{*}{ Paper } & Outp & 40100 & 25500 & 37100 & 35800 & n.s. & n.s. & n.s. & n.s. \\
\hline & tivity 93 & n.s. & n.s. & n.s. & 0.303 & n.s. & n.s. & n.s. & n.s. \\
\hline & Output growth & 12300 & 21000 & 11100 & n.s. & n.s. & n.s. & 23900 & 40600 \\
\hline & Productivity growth & 0.136 & n.s. & 0.114 & n.s. & n.s. & n.s. & 0.295 & 0.367 \\
\hline \multirow[t]{4}{*}{ Chemical } & Outp & 35400 & 60900 & 21900 & n.s. & 38300 & n.s. & n.s. & 94100 \\
\hline & tivity 93 & n.s. & n.s. & n.s. & n.s. & n.s. & n.s. & n.s. & n.s. \\
\hline & growth & 14600 & 36400 & 10500 & n.s. & n.s. & n.s. & n.s. & 51800 \\
\hline & tivity growth & n.s. & n.s. & -0.091 & n.s. & 0.229 & -0.203 & n.s. & 0.178 \\
\hline \multirow[t]{4}{*}{ Glass } & Output 93 & 62700 & n.s. & 45700 & n.s. & 96400 & n.s. & n.s. & 43000 \\
\hline & Productivity 93 & n.s. & n.s. & n.s. & n.s. & 0.320 & n.s. & n.s. & n.s. \\
\hline & growth & 18500 & n.s. & 14600 & n.s. & 30100 & n.s. & n.s. & n.s. \\
\hline & Productivity growth & n.s. & n.s. & n.s. & n.s. & n.s. & n.s. & n.s. & n.s. \\
\hline \multirow[t]{3}{*}{ Metals } & Output 93 & 175000 & 138000 & n.s. & n.s. & n.s. & n.s. & n.s. & n.s. \\
\hline & $\begin{array}{l}\text { Productivity } 93 \\
\text { Output growth }\end{array}$ & $\begin{array}{r}0.181 \\
107000\end{array}$ & $\begin{array}{r}-0.431 \\
\text { n.s. }\end{array}$ & $\begin{array}{l}\text { n.s. } \\
\text { n.s. }\end{array}$ & $\begin{array}{c}-0.908 \\
\text { n.s. }\end{array}$ & n.s. & n.s. & n.s. & $\begin{array}{l}\text { n.s. } \\
\text { n.s. }\end{array}$ \\
\hline & Productivity growth & n.s. & 0.456 & 0.359 & n.s. & n.s. & n.s. & n.s. & n.s. \\
\hline \multirow[t]{4}{*}{ Machinery } & Output 93 & n.s. & 147000 & n.s. & n.s. & n.s. & n.s. & n.s. & 207000 \\
\hline & Prodi & n.s. & n.s. & n.s. & n.s. & n.s. & n.s. & n.s. & n.s. \\
\hline & growth & n.s. & 93800 & n.s. & n.s. & n.s. & n.s. & n.s. & 162000 \\
\hline & Productivity growth & 0.065 & n.s. & 0.120 & n.s. & n.s. & n.s. & -0.214 & n.s \\
\hline
\end{tabular}

Note: Numerical entries are OLS coefficients, significant at $90 \%$ confidence level. "n.s." indicates the coefficient is not significant at $90 \%$ confidence level. 
Table 9. Distribution of plants with different exporting status conditional on the values of the first PC

\begin{tabular}{|c|c|c|c|c|c|c|c|c|c|}
\hline \multirow[t]{2}{*}{ Sector } & \multirow{2}{*}{$\begin{array}{l}\text { First PC } \\
\text { Decile }\end{array}$} & \multicolumn{2}{|c|}{ Export Status 1993} & \multicolumn{6}{|c|}{ "Dynamic Exporting Status } \\
\hline & & Non-exp. & Export & Never & Exit & Begin & orary & Multiple & Always \\
\hline \multirow[t]{3}{*}{ Food } & All & 80.8 & 19.2 & 57.0 & 2.3 & 13.4 & 7.5 & 6.0 & 13.8 \\
\hline & 1st decile & 81.8 & 18.2 & 66.7 & 4.5 & 6.1 & 6.1 & 7.6 & 9.1 \\
\hline & 10th decile & 71.6 & 28.4 & 41.8 & 0.0 & 20.9 & 7.5 & 6.0 & 23.9 \\
\hline \multirow[t]{3}{*}{ Textiles } & All & 71.2 & 28.8 & 28.4 & 3.5 & 19.1 & 15.0 & 15.2 & 18.7 \\
\hline & 1st decile & 83.3 & 16.7 & 53.7 & 7.4 & 1.9 & 20.4 & 11.1 & 5.6 \\
\hline & 10th decile & 38.2 & 61.8 & 9.1 & 0.0 & 20.0 & 7.3 & 9.1 & 54.5 \\
\hline \multirow[t]{3}{*}{ Wood } & All & 82.4 & 17.6 & 45.4 & 0.8 & 18.5 & 12.6 & 9.2 & 13.4 \\
\hline & 1st decile & 100.0 & 0.0 & 100.0 & 0.0 & 0.0 & 0.0 & 0.0 & 0.0 \\
\hline & 10th decile & 58.3 & 41.7 & 33.3 & 0.0 & 8.3 & 0.0 & 16.7 & 41.7 \\
\hline \multirow[t]{3}{*}{ Paper } & All & 79.5 & 20.5 & 51.3 & 6.6 & 11.3 & 11.6 & 12.3 & 7.0 \\
\hline & 1st decile & 90.0 & 10.0 & 73.3 & 10.0 & 3.3 & 10.0 & 3.3 & 0.0 \\
\hline & 10th decile & 51.6 & 48.4 & 25.8 & 12.9 & 16.1 & 6.5 & 19.4 & 19.4 \\
\hline \multirow[t]{3}{*}{ Chemical } & All & 61.4 & 38.6 & 29.4 & 3.3 & 15.9 & 8.3 & 15.7 & 27.4 \\
\hline & 1st decile & 76.9 & 23.1 & 44.9 & 9.0 & 9.0 & 11.5 & 15.4 & 10.3 \\
\hline & 10th decile & 27.8 & 72.2 & 7.6 & 3.8 & 12.7 & 3.8 & 11.4 & 60.8 \\
\hline \multirow[t]{3}{*}{ Glass } & All & 74.8 & 25.2 & 50.8 & 2.9 & 13.0 & 8.8 & 3.8 & 20.6 \\
\hline & 1st decile & 78.3 & 21.7 & 69.6 & 4.3 & 0.0 & 4.3 & 4.3 & 17.4 \\
\hline & 10th decile & 75.0 & 25.0 & 37.5 & 4.2 & 37.5 & 0.0 & 0.0 & 20.8 \\
\hline \multirow[t]{3}{*}{ Metals } & All & 60.2 & 39.8 & 15.3 & 4.1 & 26.5 & 12.2 & 9.2 & 32.7 \\
\hline & 1st decile & 55.6 & 44.4 & 11.1 & 0.0 & 33.3 & 0.0 & 11.1 & 44.4 \\
\hline & 10th decile & 40.0 & 60.0 & 10.0 & 10.0 & 20.0 & 10.0 & 10.0 & 40.0 \\
\hline \multirow[t]{3}{*}{ Machinery } & All & 56.2 & 43.8 & 21.6 & 4.0 & 21.2 & 9.1 & 10.6 & 33.4 \\
\hline & 1st decile & 65.1 & 34.9 & 31.4 & 3.5 & 20.9 & 9.3 & 8.1 & 26.7 \\
\hline & 10th decile & 32.2 & 67.8 & 12.6 & 1.1 & 14.9 & 1.1 & 8.0 & 62.1 \\
\hline
\end{tabular}


Table 10. Ordered probit model with deciles of the first principal component as dependent variable. Estimation result.

\begin{tabular}{|c|c|c|c|c|c|c|c|c|}
\hline Independent Variable & Food & Textiles & Wood & Paper & Chemical & Glass & Metals & Machinery \\
\hline Share of skilled workers & n.s. & n.s. & n.s. & n.s. & n.s. & 1.0265 & n.s. & n.s. \\
\hline Share of imported inputs & 0.0079 & 0.0097 & n.s. & 0.0125 & 0.0086 & 0.0099 & n.s. & 0.0055 \\
\hline Capital Intensity & 0.0006 & 0.0016 & 0.004 & 0.0009 & 0.0008 & 0.0012 & 0.0002 & -0.0005 \\
\hline Foreign Direct Investment 1993 & 0.4107 & 0.6169 & n.s. & n.s. & 0.3739 & n.s. & n.s. & 0.2881 \\
\hline \multicolumn{9}{|c|}{ Dynamic Export Status (never export omitted) } \\
\hline Stop & -0.5748 & n.s. & n.s. & n.s. & n.s. & n.s. & n.s. & n.s. \\
\hline Begin & 0.3814 & 0.8729 & 0.6741 & 0.4786 & 0.2163 & 0.7483 & n.s. & n.s. \\
\hline Temporary & n.s. & 0.2783 & n.s. & n.s. & n.s. & n.s. & n.s. & n.s. \\
\hline Multiple & n.s. & 0.6725 & 0.7206 & n.s. & n.s. & n.s. & n.s. & n.s. \\
\hline Always & 0.2876 & 1.2285 & 1.2747 & 0.8422 & 0.6154 & n.s. & n.s. & 0.386 \\
\hline \multicolumn{9}{|c|}{ Estimated cutoff points for the 10 deciles of PC1 } \\
\hline cut1 & -1.05 & -0.63 & -0.70 & -0.89 & -0.75 & -0.71 & -1.00 & -1.13 \\
\hline cut2 & -0.59 & -0.14 & -0.19 & -0.43 & -0.28 & -0.23 & -0.53 & -0.68 \\
\hline cut3 & -0.27 & 0.23 & 0.17 & -0.09 & 0.07 & 0.13 & -0.19 & -0.35 \\
\hline cut4 & 0.02 & 0.54 & 0.48 & 0.20 & 0.37 & 0.44 & 0.09 & -0.07 \\
\hline cut5 & 0.28 & 0.83 & 0.77 & 0.48 & 0.65 & 0.74 & 0.36 & 0.20 \\
\hline cut6 & 0.55 & 1.13 & 1.05 & 0.75 & 0.94 & 1.04 & 0.60 & 0.47 \\
\hline cut7 & 0.83 & 1.45 & 1.36 & 1.06 & 1.26 & 1.40 & 0.88 & 0.75 \\
\hline cut8 & 1.17 & 1.83 & 1.74 & 1.42 & 1.64 & 1.85 & 1.23 & 1.09 \\
\hline cut9 & 1.64 & 2.36 & 2.32 & 1.94 & 2.16 & 2.51 & 1.70 & 1.56 \\
\hline
\end{tabular}

Note: Numerical entries are ordered probit coefficients, significant at $90 \%$ confidence level. " "n.s." indicates the coefficient is not significant at $90 \%$ confidence level. 
Figure 1. Average probability of being in the deciles of the first principal components by dynamic export status

\section{Food Products}

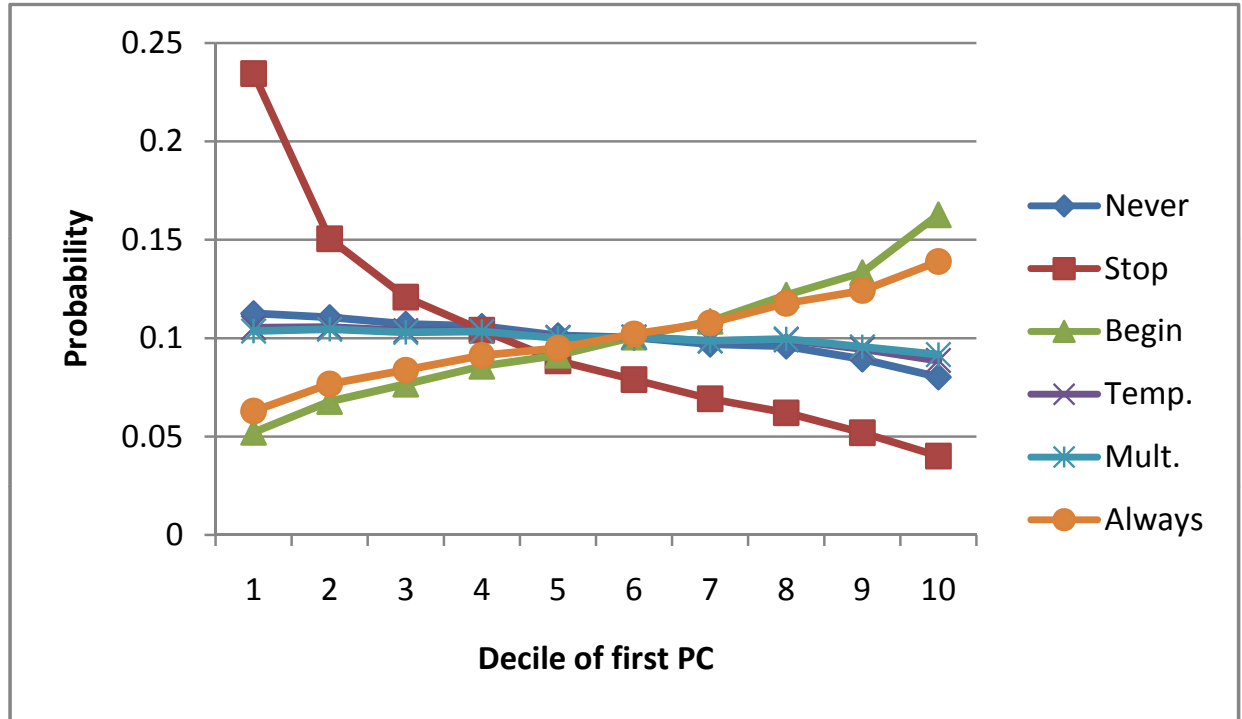

3. Wood

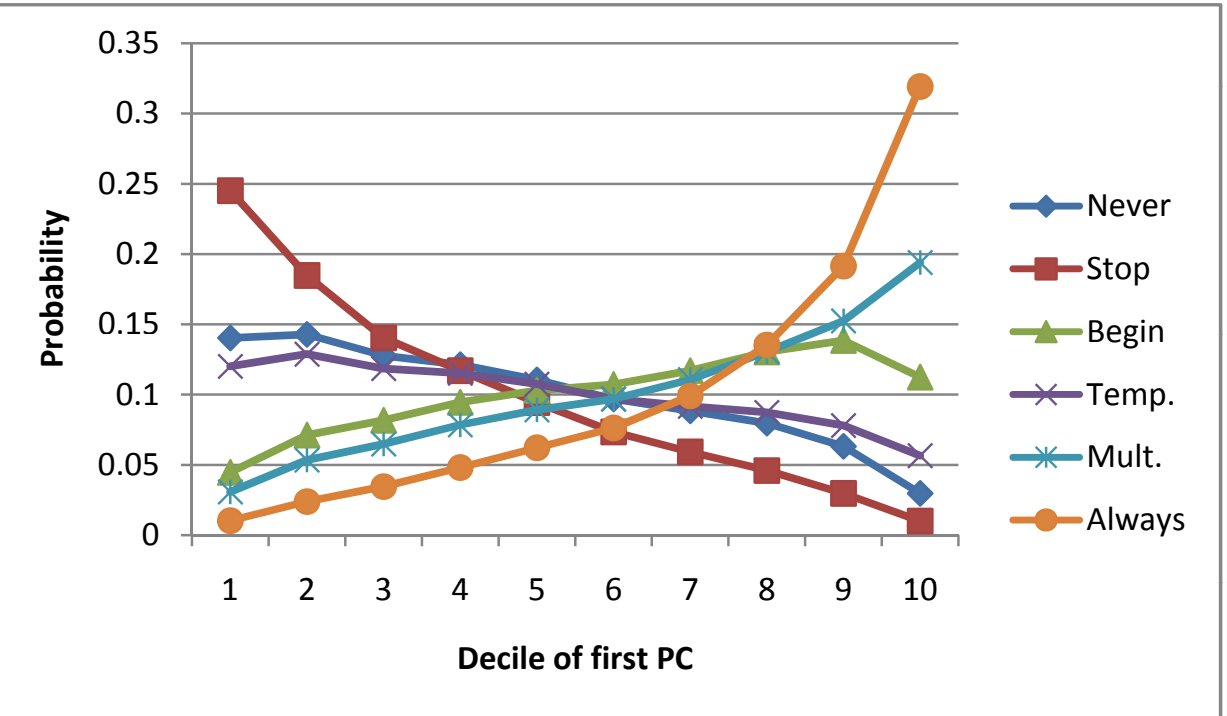

2. Textiles

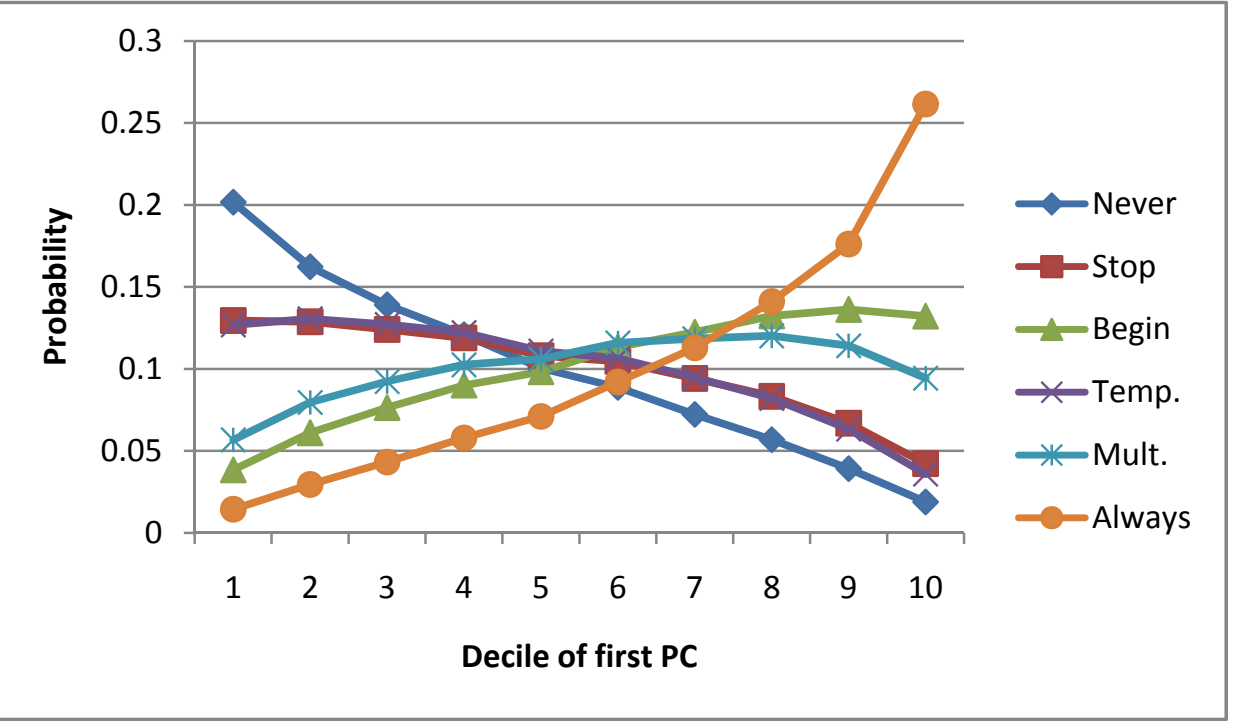

4. Paper

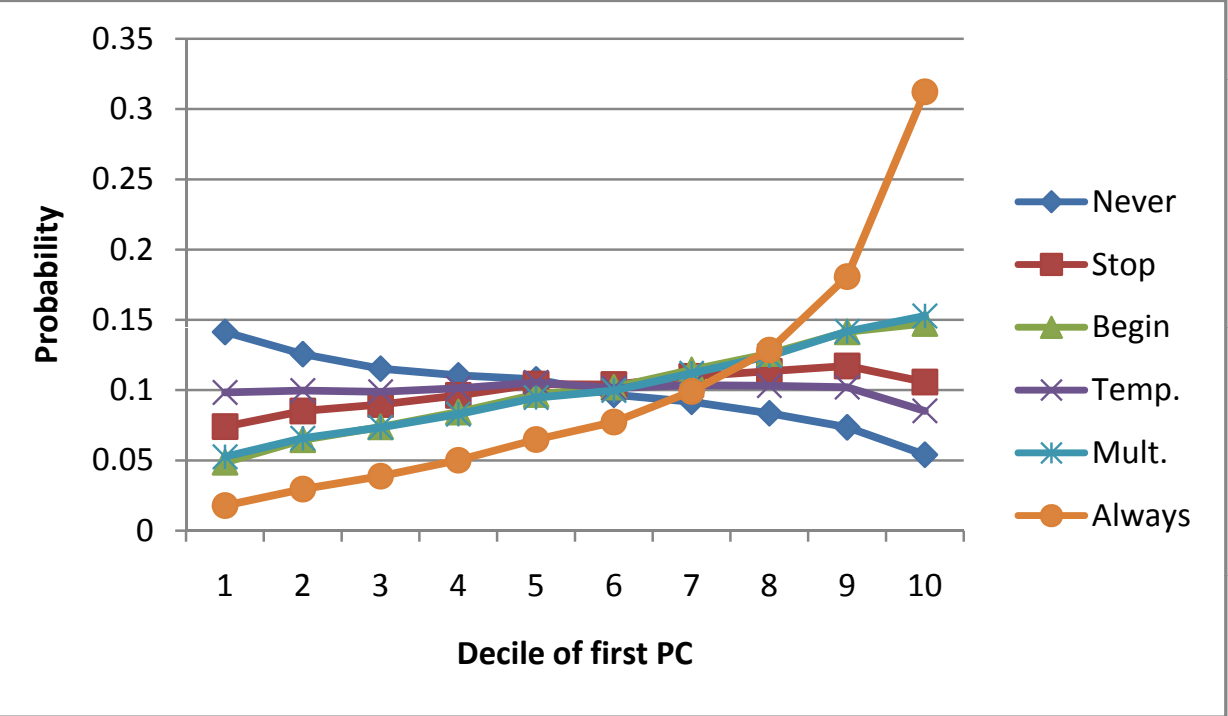




\section{Chemical}

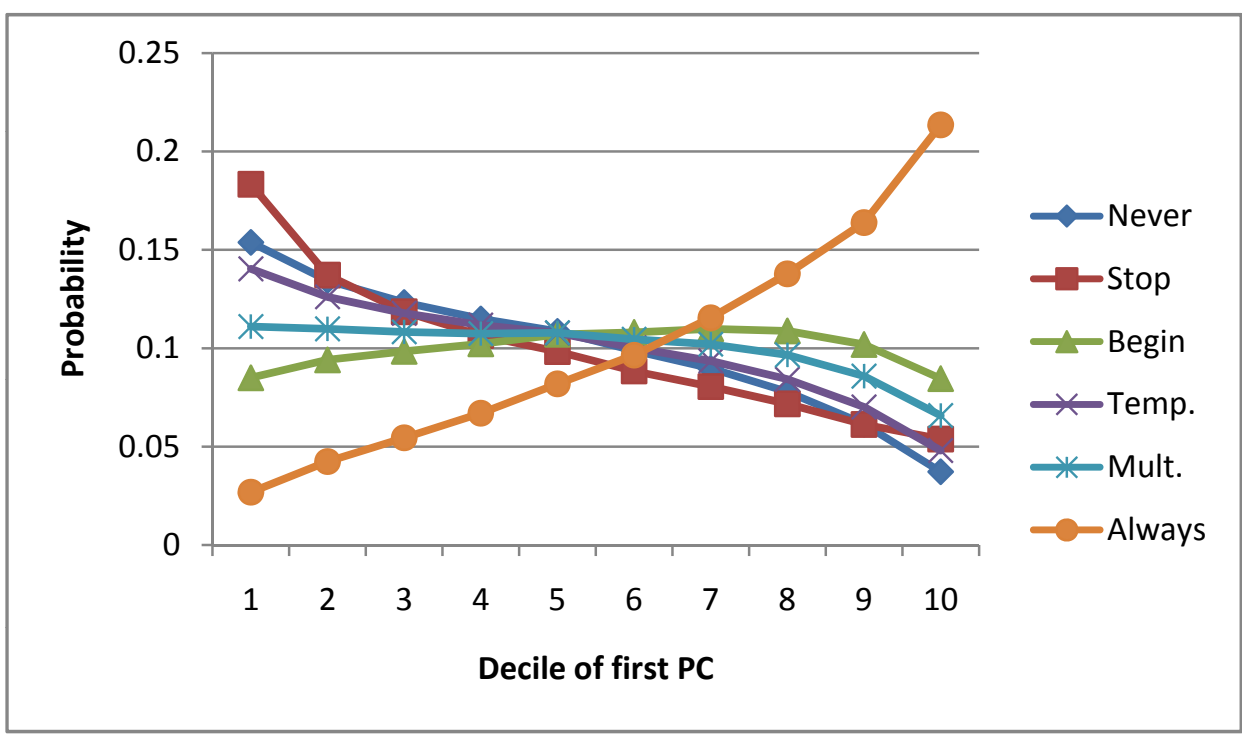

\section{Metals}

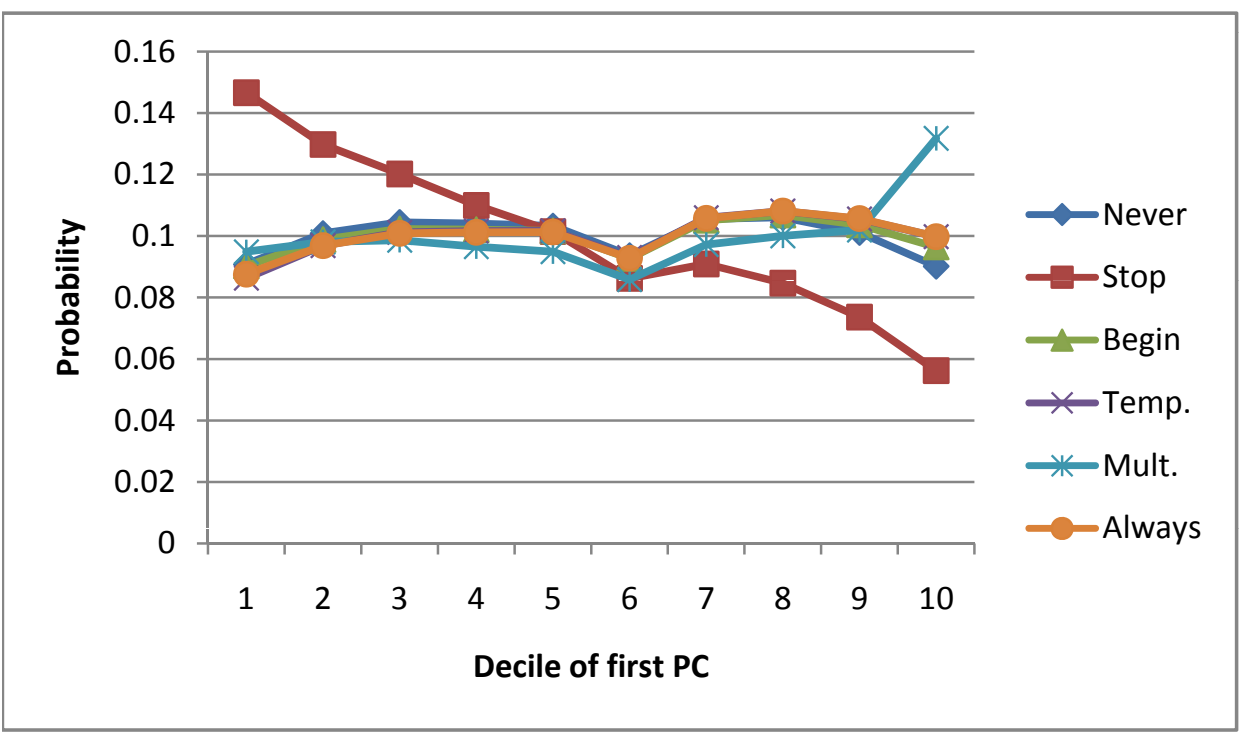

\section{Glass}

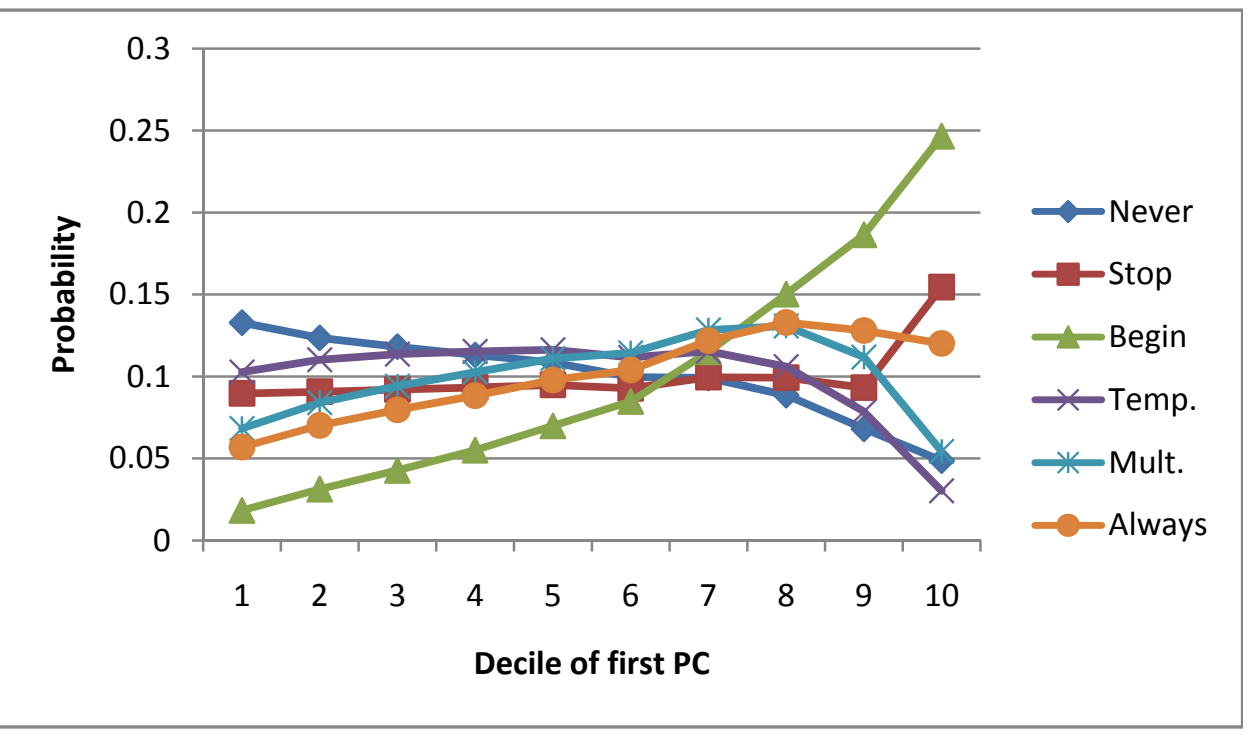

\section{Machinery}

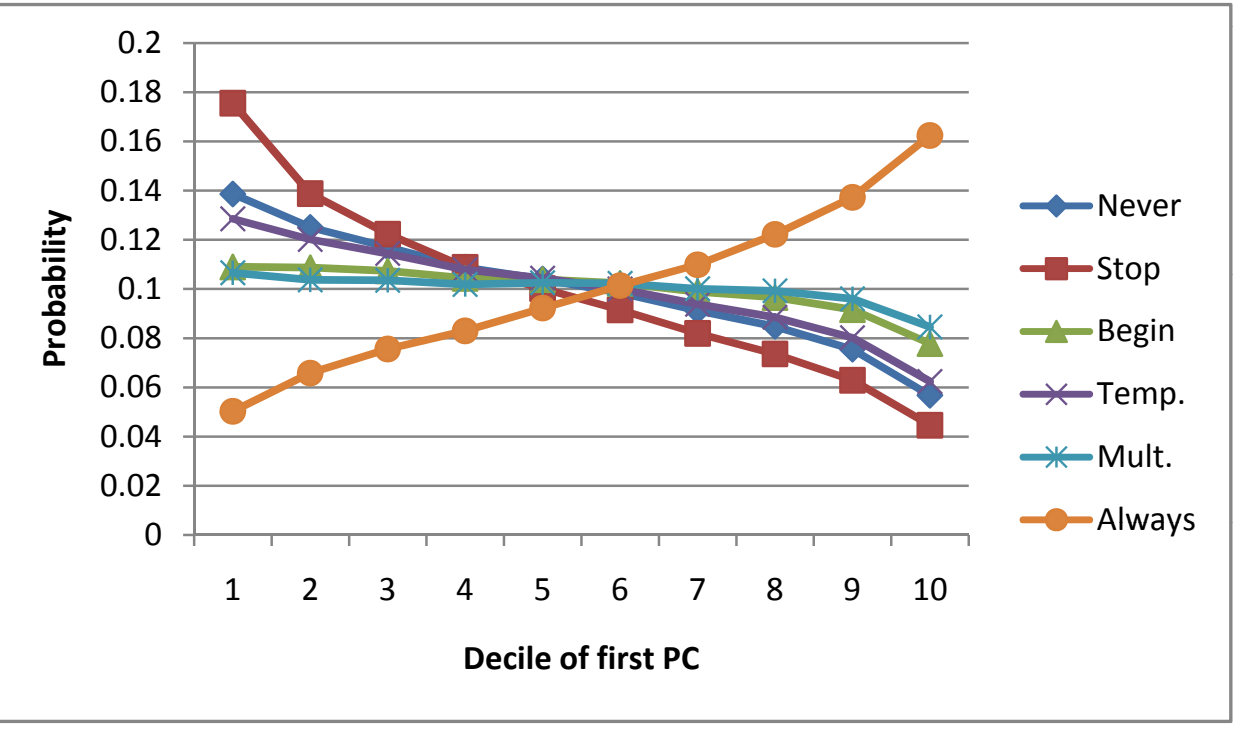

